\title{
Osmanlı Arkeolojisinin Yerel Tarihi Üzerine Bir Gözlem: Urfa'da İdareciler, Arkeologlar ve Bulgular
}

\author{
A Survey on Local History of Ottoman Archaeology: Administrators, Archaeologists and \\ Findings in Urfa
}

\author{
İsmail Asoğlu* (i]
}

\section{Öz}

Anadolu ve Mezopotamya ile bağlantısı sayesinde pek çok medeniyetin geride bıraktığı izleri taşıyan Urfa, 19. yüzyılın ikinci yarısında çok sayıda sanat tarihçisi ve arkeoloğun uğrak yeri olmuştur. Filolog Edward Sachau, Alman müzecisi ve sanat tarihçisi Friedrich Sarre, Getrude Bell, arkeolog Max von Oppenheim gibi batılı uzmanlar şehri ziyaret edenler arasındadır. Osman Hamdi Bey de Doğu turu esnasında tarihî kale ve çevresini fotoğraflamıştır. Ancak idareciler nazarında tarihî yapı ve bulgulara pek değer atfedilmemiş, kale taşları kamu yapılarını desteklemek üzere satışa çıkarılmıştır. 1891'de ise dünyanın dikkatini çeken ve Kral Abgar'a ait olduğu düşünülen üç kaya mezarı korunamamış ve buluntuların bir kısmı çalınmıştır. Hristiyanların tarihî Hıdır İlyas Manastırı ve çevresindeki mezarları sahiplenme çabası, Müslümanların tarihî Ömeriye Câmii üzerindeki tadilatları ise tamamen dinî bir bakış açısının eseri olmuştur.

Bu çalışmada, Osmanlı idarecilerinin tarihî yapı ve bulgular karşısındaki tutumları ile arkeologların Urfa yerelindeki faaliyetlerinin ortaya çıkarılması hedeflenmiştir. Çalışma sırasında Cumhurbaşkanlığı Devlet Arşivlerinde bulunan resmi kayıtlardan, gezi yazılarından ve arkeolog günlüklerinden istifade edilmiştir.

\section{Anahtar Kelimeler}

Osmanlı Arkeolojisi, Müze-i Hümâyun, Urfa, Asar-ı Atika

\section{Abstract}

Having many marks of numerous civilizations due to its link with Anatolia and Mesopotamia, Urfa became a popular destination for many art historians and archaeologists in the second half of the $19^{\text {th }}$ century. Western figures such as philologist Edward Sachau, German museologist and art historian Friedrich Sarre, Gertrude Bell, and archaeologist Max von Oppenheim were among the visitors to Urfa in that period. Osman Hamdi also photographed a historical castle and its surroundings during his East tour. However, historical sites and findings were not cared for by administrators. Castle rocks were recurrently sold to support public buildings. Three rock tombs, considered to be belonging to King Abgar, attracted much attention across the world in 1891. But, they were not protected and some of the findings were stolen. Christians' efforts to possess ancient Gregorius Peristera and surrounding graveyards and Muslims' restorations on historical Ömeriye Mosque stem mostly from religious perspective.

In this study, it is aimed to examine Ottoman administrators' attitudes towards historical sites and findings and reveal archaeologists' acts in local Urfa. To do so, the study refers to Ottoman official records kept in the Presidency's Archive, travel accounts and diaries of archaeologists.

\section{Keywords}

Ottoman Archaeology, State Museum, Urfa, Ancient Works

* Sorumlu Yazar: İsmail Asoğlu (Dr. Öğr. Üyesi), Harran Üniversitesi, Fen-Edebiyat Fakültesi, Tarih Bölümü, Şanlıurfa, Türkiye. E-posta: iasoglu@harran.edu.tr. ORCID: 0000-0002-5418-0161

Attf: Asoglu, Ismail. “Osmanlı Arkeolojisinin Yerel Tarihi Üzerine Bir Gözlem: Urfa'da İdareciler, Arkeologlar ve Bulgular.” Art-Sanat, 17(2022): 35-58. https://doi.org/10.26650/artsanat.2022.17.983246 


\section{Extended Summary}

Urfa was a significant trade and education centre that enabled the exchange of commercial products and ideas between Western and Eastern worlds. The town was one of the main destinations for many famous archaeologists and travellers in their Middle East tours in the $19^{\text {th }}$ century. Helmut Von Moltke, visiting Urfa in 1839, got pretty impressed by the city's picturesque scenes. Traveller and archaeologist Austen Henry Layard, also British Ambassador between 1877 and 1880, did not miss visiting Urfa while he was on the way back from Jerusalem in 1840 . However, for its citizens and rulers, the city wasn't as important as the foreigners thought. Historical sites and archaeological findings were not respected if no official warning was made. The stones of Historical Urfa Castle were set to the sale many times to be used in public buildings. Despite all warnings by Sublime Porte, incessant destruction of the castle couldn't be stopped till the Empire fell.

The antiques in the city weren't discovered during planned archaeological excavations but in construction projects. It was hard to transport those findings to State Museum, namely Muze-i Humayun. When an antique was wound in the late 19th century, it was first photographed and sent to Istanbul for approval. When they were found inconvenient for transportation, authorities used to get them preserved in their original places. For instance, three rock tombs discovered in an Armenian house in 1891 was preserved in their site. However, the site was ruined, and some of the findings were stolen. One of these tombs, sponsored by the municipality, was thought to be belonging to King Abgar who lived in Jesus' time. At the head of King's tomb, there was a Jesus figure illustrated with mosaic. That discovery was published in an Armenian newspaper called Aravelek in Istanbul. They reported that this discovery attracted much attention across the World.

First researches on the city were conducted by philologists, art historians and archaeologists after 1880. Osman Hamdi, the curator of the State Museum, visited Urfa during his tour to Baghdad. In Urfa, he telegrammed to his father on $13^{\text {th }}$ July 1869 , requesting him to post his books and notes. He visited Urfa during his second East tour, too. In 1883, he informed Sublime Porte about his discovery on Mount Nimrud, which attracted much press attention. Osman Hamdi went to Urfa after meeting two German researchers Carl Humman and Otto Puchstein. In late June, he re-visited Urfa and reported how warm he was welcomed. He admired city walls, photographed the castle and its surroundings, and walked in bazaars. In the early 1880s, the philologist Edward Sachau visited Balikligol (Pool of Abraham) and surrounding epitaphs. One of the early findings was an Acheuleen type hand axe discovered by archaeologist Joseph Étienne Gautier in 1884.

After the Baghdad Railway was built in the early $20^{\text {th }}$ century, the region became more significant with its geography and topography. Hence, the number of German researchers increased. Friedrich Delitzsch, a member of Berlin University and the cu- 
rator of museums, was interested in Urfa in 1902. German art historian Friedrich Sarre (1865-1945) and archaeologist, art historian, and Christian and Byzantine arts expert Ernst Herzfeld carried out researches in the region. They published all their studies in a book titled Archaeologische Reise im Euphrat und Tigrisgebiet, Berlin 1911-1920 before World War I. Thomas Edward Lawrence also researched Urfa and its surroundings. Gertrude Bell carried out some archaeological and prehistoric research in his Middle East tours. For her, Urfa and its surroundings were quite remarkable. Coming to Urfa on $17^{\text {th }}$ May 1911, Bell began wandering around the city to see Balikligol. She met the Mufti after visiting Ulu and Hasan Pasha Mosques and photographed the Castle. She described the mosque and cypresses at Balikligol as the most beautiful places in Turkey. Max von Oppenheim was another notable German traveller who visited Urfa many times. During his research tour in 1911, provincial administrations of the region were asked to respect him and allow him to take photos. However, local administrators were annoyed at Western researchers. The Aleppo governor Huseyin Kazim was worried about their activities in the region as he thought that their real aim was completely political. Yet, German researchers continued their activities in the region till World War I. In 1913, Rudolf Berliner, a German archaeologist, and Dr Emil Gratzl, the chief librarian of Munich Library and orient expert, were both interested in Urfa.

There were many holy historical structures for Muslims and Christians in Urfa. Having numerous relics from Roman, Byzantine, and Arabic civilizations, Urfa had a very significant place in the history of sanctuaries. In the late $19^{\text {th }}$ century, historical structures gained more importance for Muslim and Christian settlers. Sanctuaries contributed to maintaining faith and religious activities. They were sometimes underestimated, but ancient artefacts and the culture they belonged were significant to understanding their value in determining the city's various identities. Thereby, Muslims protected and restored historical structures. This was part of the provincial practices of Abdulhamid II's policies. For instance, the need to restore Omeru'l-Faruk mosque in Kazganc1 neighbourhood was completely related to articulating Islamic heritage in the city. Moreover, sectarian conflicts between Armenians and Assyrians drew attention, too. Particularly, claims on Gregorius Peristera monastery and surrounding graveyards turned into a lawsuit to be heard by the Kadi. Owning the historical sanctuaries meant demonstrating the culture, belonging, identity and a long-time existence. The main purpose of both Armenians and Assyrians was to officially prove their claims on the monastery and graveyards at Ottoman courts. This would also confirm the sect's longtime existence in the town. Indeed, for Muslims and Christians, this process stemmed mainly from changes in the Empire, caused by Nationalism. 


\section{Giriş}

1846-1847'de Tophane-i Âmire Müşiri Fethi Ahmet Paşa'nın St. İrene Kilisesi'nde, çeşitli vesilelerle ele geçen her türlü eski eseri depo etmeye başlaması, tartışmalı da olsa Osmanlı müzeciliğinin ilk adımları olarak görülmektedir. ${ }^{1}$ Söz konusu mekânda o vakte kadar Fâtih Sultan Mehmet zamanından beri savaşlarda ganimet olarak alınan silâhlarla artık çağdışı kalan savaş araç ve gereçler toplanmışt. ${ }^{2}$ Bu nesnelerin korunması için eski kilisenin tercih edilişi anlık ihtiyaçlardan kaynaklanmaktaydı. St. İrene Kilisesi, eskiden Hıristiyanlara ait olan İstanbul'da, Osmanlı egemenliğini sürekli olarak anımsatan fiziksel bir araç işlevine sahip oldu. ${ }^{3}$

Dönem içinde İstanbul'da kurulan ilk müze dışında; vilayetlerde de yeri, şekli ve kapasitesi bilinmeyen bazı depolar düzenlenmişti. ${ }^{4}$ Kuruluşundan yirmi yıl kadar sonra bu küçük müzenin ilk defa olarak basit bir kataloğu A. Dumont tarafindan 1867'de hazırlanıp yayınland $1 .{ }^{5} 1869$ ' da ise ilk Asar-l Atika Nizamnamesi yapıldı. ${ }^{6} 1874,1884$ ve 1906 'da yayımlanan nizamnameler ise eski eserler üzerindeki denetimi daha da sıkılaştırdı. Tarihî eserlerin yurt dışına çıkarılmalarına karşın tamamen yasaklamalara varan sinırlamalar getirildi. ${ }^{7}$

Toplanmış eserlere ilk defa müze adı, Ali Paşa'nın (1815-1871) sadrazamlığı ve Safvet Paşa'nın (1814-1883) Maarif Nazırlığı sırasında verildi. Koleksiyon Müze-i Hümâyun adını alırken başına da 8 Temmuz 1869'da Galatasaray Sultanisi öğretmenlerinden Edward Goold adında bir İngiliz atand1. ${ }^{8} 1872$ 'de Ahmed Vefik Paşa'nın Maarif Nazırı olmasıyla birlikte ise Müze-i Hümâyun Müdürlüğüne Dr. Philipp Anton Dethier getirildi. ${ }^{9}$ Dethier zamanında müze personeli giderek arttı. Kayıt, katalog ve yazışmalar için yabancı dil bilen Limoncu Efendi, Nikolaki Efendi, Fulers, Kadri Bey gibi şahıslar görev yaptı. ${ }^{10}$ Ancak Osmanlı Devleti sınırları içindeki tarihî ve sanat değeri taşıyan bütün eserleri müzecilik anlayışı içinde bir araya getiren kişi Osman Hamdi Bey olmuştu. Sadrazam İbrahim Edhem Paşanın oğlu olan Osman Hamdi

1 Ahmet Mumcu, "Eski Eserler Hukuku ve Türkiye," Ankara Üniversitesi Hukuk Fakültesi Dergisi XXVI/3-4 (1969), 65-66.

2 Erdem Yücel, "Müze,” TDV İslam Ansiklopedisi, c. 32 (Ankara: Türkiye Diyanet Vakfı Yayınları, 2006), 241.

3 Wendy M. K. Shaw, Osmanlı Müzeciliği - Müzeler, Arkeoloji ve Tarihin Görselleştirilmesi, çev. Esin Soğancılar, (İstanbul: İletişis Yayınları, 2020), 21.

4 İlber Ortaylı, "Tanzimat'ta Vilayetlerde Eski Eser Taraması," Tanzimat 'tan Cumhuriyet'e Türkiye Ansiklopedisi, c. 6 (İstanbul: İletişim Yayınları, 1985), 1599.

5 Semavi Eyice, “Arkeoloji Müzesi ve Kuruluşu," Tanzimat'tan Cumhuriyet'e Türkiye Ansiklopedisi, c. 6 (İstanbul: İletişim Yayınları, 1985), 1597.

6 Mumcu, "Eski Eserler Hukuku ve Türkiye," 66.

7 Zeynep Çelik, Asar-ı Atika-Osmanlı İmparatorluğu'nda Arkeoloji Siyaseti (İstanbul: Koç Üniversitesi Yayınları, 2016), 44.

8 Eyice, “Arkeoloji Müzesi ve Kuruluşu," 1598.

9 Ortayl, "Tanzimat'ta Vilayetlerde Eski Eser Taraması," 1599.

10 Sümer Atasoy, “Türkiye’de Müzecilik”, Cumhuriyet Dönemi Türkiye Ansiklopedisi, c. 6, (İstanbul: İletişim Yayınları, 1984), 1461. 
Bey, Dethier'in ölümü üzerine 1881'de müzenin müdürlügüne getirildi, böylece Türk müzeciliğinde yeni bir dönem başladı. ${ }^{11}$ Hamdi Bey, ölümüne kadar (1910) arkeoloji, sanat ve kültüre ilişkin konularda imparatorluğun en güçlü adamı olarak görüldü. ${ }^{12}$ Osmanlı'nın yıkılma evresinde müzecilik, eski eser gibi arkeoloji alanına mahsus terimler ve bu alandaki ilk uygulamalar Osman Hamdi Bey’in yoğun teşebbüsleriyle devlet nezdinde itibar görmeye başladı. Bu çabaları, bağlılık ve tutkusu, büyük kamusal müzelerin tarihinde benzeri olmayan bir yer edindi. ${ }^{13}$ Onun göreve gelmesiyle Osmanlı arkeoloji tarihi Osman Hamdi Bey tarafından kurgulanmaya başladı. ${ }^{14}$

Bu çabalar, modernite dinamiğiyle de bağlantılı olup ${ }^{15}$ Osmanlı'daki Batılılaşma dalgasının en belirgin sonuçlarından biriydi. Hatta ilk müzenin açılışı, Batı'nın hegemonik söylemine karşı atılan bir adımdı. Böylece Osmanlı, Greko-Romen antikalarını kendi tarihine entegre ederek "yerli” kılmaya çalışıyordu. ${ }^{16} 1892$ 'ye gelindiğinde gazeteler, Müze-i Hümayun'un şöhretinin Avrupa'ya yayıldığından bahsetmeye başladı. ${ }^{17}$ Batı dillerine tercüme edilen antik kaynakların Avrupa' da merak uyandırması ise pek çok gezgini Osmanlı topraklarında araştırmaya yapmaya yöneltti. Batılı devletlerin eski eser yağmasını dış politikalarının bir parçası hâline getirmeleriyle ${ }^{18}$ de Osmanlı sahasındaki eserlerin yurt dışına çıkarılması artarak devam etti. Geçmişin somut değerleri sömürgeciliğin bir parçası hâline gelmişti. Bu nedenle Bernard Lewis’in de belirttiği gibi objeler "tarihsel sürecin herhangi bir yorumu için artı önem arz etmeye başlamıştı."19 Ancak dönemin idarecileri için eski eserler, endişelenecek veyahut değer atfedecek kadar önem taşımamaktaydı. Vesikalarda "sütun” yerine "direk”, "kaya mezarı" yerine "mağara" gibi ifadelerin kullanılmış olması, alana dair terminolojinin henüz oluşmadığına işaret etmektedir. Şehir sakinlerinin ve idarecilerinin eski eserlere ilişkin dünyaları, daha çok 1868 ile 1908 yılları arasında yayımlanan salnamelerdeki kısa tanıtımlarla sınırlıydı. Taşradaki bulguların akıbeti ise Dersaadet'ten sağlanacak mali destek, bulguların taşınabilir olması ve Müze-i Hümâyun'da teşhir değerine göre değişebilmekteydi. Özellikle taşınamayacak durumda olan eserlerin bulunduğu yerde muhafaza edilmesi isteniyordu.

11 Filiz Gündüz, "Osman Hamdi Bey,” TDV İslam Ansiklopedisi, c. 33 (Ankara: Türkiye Diyanet Vakıf Yayınlar1, 2007), 468.

12 Edhem Eldem, "An Ottoman Traveler to the Orient Osman Hamdi Bey," Poetics and Politics of Place Ottoman Istanbul and British Orientalism, der. Zeynep İnankur, Reina Lewis ve Mary Roberts (İstanbul: Pera Müzesi, 2011), 169.

13 Çelik, Asar-ı Atika-Osmanlı Imparatorluğu'nda Arkeoloji Siyaseti, 45.

14 Edhem Eldem, Mitler, Gerçekler ve Yöntem Osmanlı Tarihinde Aklıma Takılanlar (İstanbul: Tarih Vakfı Yurt Yayınları, 2018), 7.

15 Uzi Baram ve Lynda Caroll, Osmanl Arkeolojisi (İstanbul: Kitapyayınevi, 2004), 145.

16 Margarita Diaz-Andreu, A World History of Nineteenth-Century Archaeology: Nationalism, Colonialism, and the Past (Oxford: Oxford University Press, 2008), 111.

17 Çelik, Asar-ı Atika-Osmanlı Imparatorluğu'nda Arkeoloji Siyaseti, 41.

18 Halit Çal, "Osmanlı Devletinde Âsâr-1 Atîka Nizamnâmeleri”, Vakıflar Dergisi 26 (1997), 394.

19 Baram ve Caroll, Osmanll Arkeolojisi, 143. 


\section{Urfa'da İdareciler, Arkeologlar ve Bulgular}

Büyük İskender'in Selevkoslu halefleri Urfa'yı Edessa olarak isimlendirmiş ve akabinde şehir Doğu ile Batı arasında hem ticarî açıdan hem de öğrenim bakımından önemli bir merkez olmuştu. ${ }^{20}$ Kentin içinde bulunduğu saha, tarih öncesinde olduğu gibi Roma, Osrhone ve Müslümanların fetih dönemlerinde söz konusu önemini korumaya devam etmişti. ${ }^{21}$ Bundan dolayı şehir, dünyadaki pek çok halkın bölgesel muhâkemesinin kavşağında yer almaktaydı. ${ }^{22} 19$. yüzyılın ikinci yarısı itibarıyla seyyahların, misyonerlerin, arkeolog ve sanat tarihçilerinin şehri ziyaret edişi söz konusu tarihsel geçmişinden dolayıydı. Dışarıdan şehre giren bir yabancının dikkatini çeken ilk şey, kale ve surlarla çevrili şehrin pitoresk görüntüsü olmaktayd $1 .{ }^{23} 1839$ 'da Urfa'y1 ziyaret eden Helmut Von Moltke, zarif taştan yapılmış evlerden, ince sütunlardan, sivri kemer ve çeşmelerden çok etkilenmişti. ${ }^{24} 1840$ yılının Şubat ayında ise Kudüs'ten dönen arkeolog, seyyah Sir Austen Henry Layard (1877-1880 y1lları arası İngiliz büyükelçisi) Urfa'ya uğramadan bölgeden ayrılmamıştı. ${ }^{25}$

Hz. İbrahim'in kaleden atılışına ilişkin kutsal bir anlatıya sahip Urfa kalesi ve surları ${ }^{26}$ şehrin varlığını görünür kılan en eski yapılardan biriydi. Ancak şehir ricalince tarihî eserlere atfedilmeyen değerden dolayı yapı belirli aralıklarla tahrip edilmişti. Pek çok idareci şehrin bentlerini, sarayını ve çeşitli kamu yapılarını, gerektiğinde kale taşlarıyla yeniden inşa ettirmişti. ${ }^{27}$ Tarihî yapıya verilen zarar uygunsuz görülse de Bâb-1 Âli'nin yeterli bir muhafaza politikası uygulanamadı. Yerel idarece kaleye verilen tahribat birkaç nedene dayandırılmaktaydı. İç kaledeki hanelerin sahipsizliği ve iki üç bin yıllık, eski ve harabe oluşları tahribat gerekçeleri arasındaydı. Zaman zaman kale taşları satışa dahi çıkarıldı. Taş alıcıları ekseriyetle şehrin muteberleriydi.

20 Gordon Severance ve Diana Severance, Against the Gates of Hell: The Life \& Times of Henry Perry, A Christian Missionary in a Moslem World (USA: University Press of America, 2012), 71.

21 Abdullah Ekinci, Müze Şehir Urfa (Ankara: Şanlıurfa İl Kültür ve Turizm Müdürlüğü Yayınları, 2006), 1.

22 Michel Bruneau, Kü̧̈ük Asya'dan Türkiye'ye Azınlıklar, Etnik-Milli Homojenleştirme, Diasporalar (İstanbul: İletişim Yayınları, 2018), 21.

23 James Silk Buckingham, Travels in Mesopotamia (London: D. S. Maurice, 1827), 51; George Percy Badger, The Nestorians and Their Rituals: with the Narrative V. 1 (London: J. Masters and Co. Printers, 1852), 322; Helmuuth Von Moltke, Moltke'nin Türkiye Mektuplarl, çev. Hayrullah Örs (İstanbul: Remzi Kitabevi, 2017), 235; Eduard Sachau, Reise in Syrien Und Mesopotamien (Leipzig: F.A. Brockhaus, 1883), 192-193; Francis Rawdon Chesneys, Narrative of the Euphrates Expedition 1835, 1836 and 1837 (London: Printed by Spottiswoode \& Co, 1868), 419.

24 Moltke, Moltke'nin Türkiye Mektupları, 235.

25 Yuluğ Tekin Kurat, Henry Layard'in İstanbul Elçiliği, 1877-1880 (Ankara: Ankara Üniversitesi Dil ve Tarih-Coğrafya Fakültesi Yayınları, 1968), 4.

26 Urfa Kalesi ile ilgili ilk kayıtlar 11. yüzyıla aittir. 6. yüzyılın yazılı kaynaklarında ise şehir surlarından bahsedilmez. Surların yapım tarihlerinin 6. ile 11. yüzyıllar arası olduğu düşünülmektedir ve büyük bir bölümü 20. yüzyılın başında yıkılmıştır. Bk. Abdullah Ekinci, Şanlıurfa and Harran (Ankara: Republic of Turkey Ministry of Culture and Tourism Directorate General of Libraries and Publications, 2015), 41-42.

27 Başkanlık Osmanlı Arşivi (BOA), Meclis-i Vâlâ (MVL) 23/14-3, 20 Cemaziyelevvel 1264 (29 Nisan 1848). 
Bu gibi durumlarda kimlere taş satılacağ önceden belirlenir, ${ }^{28}$ satış hususunda merkezden herhangi bir izin almaya lüzum görülmezdi.

Kaleye verilen zarardan doğan yereldeki tartışmalar, 19. yüzyılın ortalarında mahallî bürokrasiyi uzun yıllar meşgul eden konulardan oldu. ${ }^{29} 1848$ ' deki taş alıcılarından biri meclis azası ve iskân kâtibi Sakıp Efendi isminde şehir muteberlerindendi. Kurduğu vakfin bünyesinde han, tekke, medrese gibi yapılar inşa ettirmesiyle tanınan Sakıp Efendi, kaleyi tahrip ettirmek ve şahsına ait hususi bir konak yaptırmakla suçlanmışt1. ${ }^{30}$ Verilen zararın tahkiki amacıyla kadı, müftü gibi pek çok idarî kademeden yetkilinin bir araya gelmesi mevzunun şehir idaresini hayli meşgul ettiğini gösteriyordu. İdarî tedbirle taşların fiyatı, yeniden inşası ve gereken masrafın tespiti için belde mimarı görevlendirilmiş, ${ }^{31}$ ilgili raporlar düzenlenmiş, kalenin eski ve büyük yerlerinin bertaraf edildiği kayda geçirilmişti. ${ }^{32}$

Halep'ten gönderilen Mübaşir Ahmet Efendi'nin raporuna göre kaymakam, meclis azaları ve taş müşterileri kaleye verilen zarardan müştereken sorumluydu. Her grup kendi işine yarayacak surette ifade verdiğinden mevzu uzun süre çözümlenemedi. ${ }^{33}$ Bâb-1 Âli, kalenin tahribatı sabit ise cezanın icra edilmesini, iftira ise müfterinin cezalandırılmasını istiyordu. ${ }^{34}$ Aslında Bâb-1 Âli'nin bu tavrı, o yıllarda yerleşik bir eski eser politikasının mevcudiyetine işaret etmemektedir. Kale tahribatından dolayı yerel siyasete yön veren seçkinler arasındaki uyuşmazlık, idari işleyişi kesintiye uğratmaktaydı. Bundan dolayı sorunun bir an önce çözümlenmesi gerekmişti. Tarihî kale üzerinden siyaset, yerel hizipleşmenin aralıklarla malzemesi olmaya devam etti. ${ }^{35}$ Aradan geçen zamana rağmen kaleye verilen zarar, kanunlara rağmen durdurulamad. Mayıs 1909'da kale yıkıntılarının parça parça satılması ve paranın bir kısmının Sanayi Mektebine, diğer yarısının ise Belediyeye verilmesi hususunda Harbiye Nezaretine

28 Daha sonraki yıllarda yerel idarecilerin bu tür davranışlarının önüne geçilmeye çalışıldı. 1884 tarihli nizamname ile taşınmaz eserlerin tahrip edilmesi, değiştirilmesi, çevrelerinde zarar verici işlemlerde bulunulması ve değerlerine uygun olmayan işlerde kullanılması yasaklandı. Bk. Necva Akçura, "Türkiye ve Eski Eserler," Mimarlık Dergisi 8 (1972), 40

29 BOA, MVL. 23/14.

30 Konağın 800 kese akçe gibi yüksek bir meblağa inşa edilebileceği belirtiliyordu: BOA, MVL. 23/14.

31 Başkanlık Osmanlı Arşivi (BOA), A. Sedaret-Mektubi Kalemi Evrakı (MKT) 110/64; BOA, MVL. 23/14.

32 İlk suçlama meclis reisi Fazlullah’tan gelmiş ve bu konuda Halep valisi bilgilendirilmiştir. Sakıp Efendi'nin kaleden ruhsatsız surette tahrip ettirdiği yerler; kale kuyusu yakınındaki kuleler, mancınık uğrunda bir bölüm, yel değirmeni ve etrafındaki duvarların birer katı şeklinde raporlanmıştır. Yıkılmış yerlerin duvarlarını heyet-i asliyesine çevirmenin iki yük doksan bir bin beş yüz kuruş olabileceği Urfa'daki bina taifesinin cümlesinin ortak kararıyla belirlenmiştir: BOA, MVL. 23/14.

33 Başkanlık Osmanlı Arşivi (BOA), A. Sedaret-Meclis-i Vâlâ Evrakı (MKT.MVL) 26/28, 25 Cemaziyelevvel 1266 (8 Nisan 1850).

34 Başkanlık Osmanlı Arşivi (BOA), A. Sedaret-Nezaret ve Devair Evrakı (MKT.NZD) 74/32, 26 Cemaziyelevvel 1269 (7 Mart 1853).

35 Urfa müftüsü, 1861'de Sakıp Efendi'yi Urfa'yı istila ile suçlamış ve onu din ü devlete ihanetle itham etmiştir. Oysa Mutasarrıf, Sakıb Efendi’yi hayır sahibi, vakıf kuran biri olarak tanıtmıştır. Başkanlık Osmanlı Arşivi (BOA), A. Sedaret-Umumî Vilâyat Evrakı (MKT.UM) 490/17, 1 Safer 1278 (8 Ağustos 1861). 
başvuruldu. ${ }^{36}$ Gereken izinler muhtemelen Osman Hamdi Bey'in 24 Şubat 1910'daki ölümünden sonra alınmıştı. Zira bir komisyon marifetiyle müzayede yapılmış ve kale taşları yeniden satışa çıkarılmıştı. ${ }^{37}$ Ancak bu defaki tahribat, Times gazetesinin 9 Ağustos 1911 tarihli nüshasında, "Kuzey Suriye ve Mezopotamya'da Vandalizm" başlığı altında neşr olunmuştu. II. Abdülhamid dönemine nazaran Jön Türkler'in ilerlemeciliğine dikkat çeken gazete haberi, Urfa, Rumkale ve Birecik’teki kale taşlarının satışı konusunda İttihad ve Terakki yönetimini ilgisizlikle itham etmekteydi. ${ }^{38}$

Antik bulgulara daha çok inşa çalışmaları esnasında rastlanıyordu. Taşınabilir ve sergilenmeye değer olan buluntular, Müze-i Hümâyun'a gönderilirken taşınması mümkün olmayan bulgular yerelde muhafaza edilmeye çalış1lyyordu. Urfa gibi merkezden uzak bölgelerdeki buluntuların akıbeti, Müze-i Hümâyun'da sergi değerlerine göre değişebilmekteydi. Öncelikle bulguların fotoğrafları İstanbul'a gönderilmekteydi. Resimler inceleniyor ona göre müzeye gönderilip gönderilmeyeceğine karar veriliyordu. ${ }^{39} \mathrm{Bir}$ kahvehane inşaatında rastlanan üç kaya mezarına ilişkin yürütülen işlemler, sürecin nasıl işlediğini açıkça göstermektedir: Kazı yerel idarece durdurulmuş ve alan korumaya alınmışt1. ${ }^{40}$ Yeterli surette olmasa da bu durum, arkeolojik bulgulara karşı yereldeki tavrın değişmeye başladığına işaretti. Kaya mezarlarından birinde mavi, sarı ve pembe taşlarla işlenmiş erkek ve kadın, küçük ve büyük on dört resme rastlandığından bahsedilmekteydi. Üzerindeki Süryanice yazıya nazaran bir aile kabristanı olduğu anlaşılan yerin resimleri çıkarılmış, ekleriyle birlikte müzeye havale edilmişti. ${ }^{41}$ Süryanice yazılı mezar taşının tek parça hâlinde çıkarılması zor olduğundan, ${ }^{42}$ müze müdürü Osman Hamdi Bey, keşfin mahallinde muhafazasını uygun görmüştü. ${ }^{43}$

Urfa bölgesi, Osman Hamdi Bey'in daha öncesinde ziyaret ettiği şehirler arasındaydı. 1869'da Fransa'dan Türkiye'ye çağırılarak Bağdat vilâyeti Umûr-1 Ecnebiye Müdürlüğüne tayin edilmişti. ${ }^{44}$ Anlattığı hikâyeleri not ederek daha sonra yayımlayan yakın dostu Alman muharrirlerinden Rudolf Lindau'nun "Bir Efendinin Hikâyeleri" 45 adlı çalışmasına göre Osman Hamdi Bey Urfa'da birkaç gün mola vermişti. Kitap ve

36 Başkanlık Osmanlı Arşivi (BOA), Dahiliye-Mektubî Kalemi (DH.MKT) 2801/71, 4 Rebiülahir (4 Mayıs 1909).

37 Başkanlık Osmanlı Arşivi (BOA), Maliye Nezareti Emlaki Emiriyye Müdüriyeti (ML.EEM) 847/24, 26 Mart 1327 (8 Haziran 1911).

38 Traveller, "Vandalism in Upper Syria And Mesopotamia," Times, 9 Ağustos 1911, 10.

39 Başkanlık Osmanlı Arşivi (BOA), Maarif Nezareti-Mektubi Kalemi (MF.MKT) 1153/53-1-2, 17 Mayıs 1326 (30 Temmuz 1910).

40 BOA, DH.MKT. 1608/42; BOA, DH.MKT. 1622/25.

41 Hükümet konağının kuzeyinde, Karakoyun deresinin ittisalindeki inşa kazısında rastlanan mezar yeri, redif deposuna yirmi otuz arşın mesafedeydi. BOA, DH.MKT. 1622/25.

42 BOA, DH.MKT.1610/12; BOA, DH.MKT. 1623/132; BOA, MF.MKT. 108/30, 108/75; Başkanlık Osmanlı Arşivi (BOA), Yıldız Zaptiye Nezareti Maruzatı (Y.PRK.ZB) 4/68, 8 Recep 1306 (10 Mart 1889).

43 BOA, MF.MKT. 108/75.

44 Arif Müfid Mansel, "Osman Hamdi Bey”. Belleten XXIV/94 (1960), 292.

45 Mansel, “Osman Hamdi Bey,” 293. 
notalarını göndermesi için babasına yolladığı mektubu Urfa'dan yazmıştı. ${ }^{46}$ Şehri harikulade bulan Osman Hamdi Bey, surlara hayran kalmış, Halilürrahman Camii'nde dua etmeyi ihmal etmemişti. ${ }^{47}$ Bir sonraki Urfa ziyareti ise 1883 yılı içerisinde olmuştu. Bu yolculuk, 1869 ve 1871 Bağdat gezilerinden sonraki ikinci büyük Doğu seyahatiydi. Özel amacı ise yeni keşfedilen Nemrud Dağı'ndaki Kommageneli Antiochos Tümülüsü'nü gezmekti. ${ }^{48}$ Nemrud Dağ çevresinde araştırmalarda bulunurken Alman araştırmacılar Carl Humann ${ }^{49}$ ve Otto Puchstein ile tanıştıktan sonra Urfa'ya geçmişti. Nemrud Dağı'ndaki keşif haberi telgrafla Urfa'dan İstanbul'a bildirilmişti. Gazetelere gönderilen haber, “İmparatorluk müzesi müdürü Hamdi Bey, Nemrud Dağı'nda ne yazık ki taşınamayan (Dersaadet'teki müzeye) büyük öneme sahip antikalar keşfetti" 50 şeklinde yayımlanmıştı. 1883 yılının Haziran ayı sonlarında tekrar Urfa'ya uğrayan Osman Hamdi Bey, samimiyetle ağırlandığına dikkat çekmişti. Bu gelişinde kale ve çevresini fotoğraflamış, şehrin çarşılarını dolaşmıştı. Sonraki durağı ise eski kalıntıların yer aldığı söylenen Suruç/Arslantaş olmuştu. ${ }^{51}$

Şehir ve çevresinde rastlanan eserlerin tarihlendiği zaman, ait olduğu medeniyet, ahalice gösterilen ilgide belirleyici olmaktaydı. Ortaya çıkan eserlerin Müslüman, Hristiyan ya da Yahudiler'e ait bir iz taşıyor oluşu önemliydi. Çünkü 19. yüzyıl boyunca ve özellikle 20. yüzyılın başlarında Osmanlı vatandaşları, kimliklerini daha görünür kılmak adına bir yarışa girmişlerdi. Etnik, dilsel ve dinî ilişkiler yeniden müzakere ediliyor veyahut tanımlanıyordu. Ulusal kimliklerin yaratılışı, önemli ölçüde, yakın geçmişte değil, antik dönemde kurulan bu çevrede yaşamış insanların ortak köklere sahip olduğu fikrine dayandırılmaya başlanmıştı. ${ }^{52}$ Dil ve tarih anlayışı etrafında kristalleşen ulus bilinciyle ${ }^{53}$ beraber her topluluk eski eserleri kendi medeniyetinin yaşadığı topraktaki geçmişinin kanıtı olarak saymaya başlamıştı.

46 Edhem Eldem, "Osman Hamdi Bey'in Bağdat Vilâyeti'ndeki Görevi Sırasında Babası Edhem Paşa'ya Mektupları," 1. Osman Hamdi Bey Kongresi Bildiriler 2-5 Ekim 1990, haz. Zeynep Rona (İstanbul: Mimar Sinan Üniversitesi Yayınlar1, 1992), 67; Edhem Eldem, Un Ottoman En Orient Osman Hamdi Bey en Irak, 1869-1871 (Paris: Actes Sud, 2010), 71. “Osman Hamdi Bey'in Bağdat Vilayeti’ndeki Görevi Sirasında Babası Edhem Paşa'ya Mektupları" isimli bildiriyi paylaşma nezaketinde bulunan Prof. Dr. Edhem Eldem'e teşekkür ediyorum.

47 Eldem, Un Ottoman En Orient Osman Hamdi Bey en Irak, 1869-1871, 119.

48 Eldem, "An Ottoman Traveler to the Orient Osman Hamdi Bey," 172.

49 Osman Hamdi Bey kazı hususunda kendisine yardımda bulunmuş olan iki Alman bilginini -Bergama kazılarıyla şöhret kazanmış olan Carl Humann ve Alexander Conze'yi- şükranla yâd eder ve şöyle der: "Humann'dan kazı yapmağı öğrendim". "Conze, kendisine bildirdiğim her başarıya, kendinin başarısı imiş gibi, sevinirdi; bunu birçok defalar sözlü ve yazılı olarak ifade etmiş ve bana daima yeni teşebbüslerde bulunmak cesaretini vermiştir.” Mansel, “Osman Hamdi Bey," 295-296.

50 Edhem Eldem, Le Voyage à Nemrud Dağı d'Osman Hamdi Bey et Osgan Efendi (1883) (Paris: De Boccard, 2010), 26; Herman A. G. Brijder, "Other Expeditions and Discoveries, in the Later $19^{\text {th }}$ Century," Nemrud Dağg (Recent Archaeological Research and Preservation and Restoration Activities in the Tomb Sanctuary on Mount Nemrud) (Berlin: De Gruyter, 2014), 195-196; Ayrıca La Turquie gazetesindeki haber için bk. "Le Musée Imperial," La Turquie, 5 Juin, 1883, erişim 4 Nisan 2021, https://archives.saltresearch.org/handle/123456789/129158.

51 Eldem, Le Voyage à Nemrud Dağ̀ d'Osman Hamdi Bey et Osgan Efendi (1883), 71-72.

52 Baram ve Caroll, Osmanlı Arkeolojisi, 20.

53 Jürgen Habermas, "Öteki” Olmak, "Öteki” İle Yaşamak, çev. İlknur Aka, (İstanbul: Yapı Kredi Yayınları, 2012), 21. 
Şehrin Hristiyanlık geçmişine ait buluntular Ermeni ve Süryani sakinler nazarında daha da önem arz etmekteydi. 1891'de bir Ermeni hanesindeki tadilat esnasında ortaya çıkan birkaç kaya mezarı, o günlerde yabancı basının dikkati çekmişti. İstanbul'da Ermenice yayımlanan Aravelek gazetesinin (22 Ekim 1891) haberine göre kazı masrafı belediyece karşılanmıştı. ${ }^{54}$ Evin zemininde mozaiklerle döşenmiş bir kemer yer alırken kemerin altında ne zaman kazınmış olduğu bilinmeyen bir haç işareti fark edilmiş̧i. Kemerin içine doğru bir buçuk metre aşağı inildiğinde yere dökülmüş ve türlü resimler barındıran bir hayli taş ile karşılaşılmıştı. İçeriye doğru yol açmak maksadıyla taşlar çifte kemerin orta yerlerinden sökülmüştü. Sağ tarafta tek parça taştan oyulmuş ve batıdan doğuya doğru yerleştirilmiş büyük bir mezar taşı bulunmaktaydı. İlk dikkati çeken şeyler taşın içinde ve kapağı üstünde küle dönmüş insan kemikleriydi. Mezarın baş tarafında dikkate şayan bir iki işaret fark edilmişti. Tavan ve duvarlardaki kaba sıvaların üzerinde rengârenk nakışlar mevcuttu. Lakin asırlardır oluşan rutubetten büyük kısmı dökülmüştü. Mezar alanı şark tarafından bir orta duvar ile ayrılmıştı. Duvarın üzerinde yine tek parça taştan imal edilmiş ve bir metre uzunluğunda, yetmiş beş santimetre eninde bir kapı yer almaktaydı. Kapının üstündeki taşta titizlikle kazınmış iki heykelden birinin kadın olduğu tespit edilmişti. Tavan ve dört duvarı mozaik ile süslenmiş odalardan biri hükümdar mezarını andırmaktaydı. Kuzey, doğu ve batı cihetlerinde bulunan üç adet mezarın duvarlarındaki mozaiklerin pek çoğu dökülmüştü. İnsan resimlerinin ancak yarısı bir gölge misali seçilmekteydi. Tepelerinde kandil asmaya mahsus olduğu düşünülen çivi mahallerinin izleri görülmekteydi. Kuzey tarafında bulunan mezarın kenarı çiçek, batı tarafındaki mezarın kenarı üzüm salkımı ve asma yaprakları ile kazınmıştı. Orta yerindeki mezarın kenarına, hayrete şayan derecede bir hiza ile işlenmiş sekiz adet insan başı kazınmıştı. Bunların ara yerlerinde beş kısma ayrılmış olarak yedi adet mürdegân (ölüler) çiziliydi. Mezarın baş tarafındaki çiçeklerin arasında mozaik ile resmedilmiş Hz. İsa'nın siması bozulmamış hâlde durmaktaydı. Yarım metre uzunluğundaki mezarın Hz. İsa zamanındaki Abgar adlı hükümdara ait olduğu tahmin edilmişti. Burada eserin neyi tasvir ettiği, dinsel ya da din dışı biçimi önem kazanmaktadır. Üzüm salkımı ya da başak demeti gibi bitkiler, Dominik Bonatz'ın Kuzey Suriye ve Güneydoğu Anadolu bölgelerinde hanedan üyelerinin şehir içerisinde çeşitli uygulamalarla yüceltilmelerine yönelik değerlendirmesi kapsamında ele alınabilir. İktidar alanında hanedan üyelerinin muktedir olma vasıflarını, depolardaki tahıl ve şarap stoku ile dile getiriyor olmaları söz konusu bitki çiftine gösterdikleri bu itibarı gerekçelendirmek için uygun bir zemin sağlamaktadır. ${ }^{55}$

Vilayet mühendisinin emriyle açılan mezarın ortası dört köşeli ve renkli bir çerçeve ile ayrılmıştı. Orta yerinde taçlı ve ihtiyar çehreli bir erkek resmi yer almaktaydı.

54 BOA, MF.MKT. 132/43.

55 Gökhan Tiryaki, "Yeni Hitit Sanatı Üzerine İkonografik Araştırmalar 1: Üzüm Salkımı ve/veya Başak Filizi Taşıyanlar," CEDRUS The Journal of MCRI 1 (2013), 41-42. 
Resmin yanında, aynı vaziyette bir çocuk resmi mevcuttu. Üçüncü resim sakallıydı ve başını taçlı insanın dizine koymuş şekilde durmaktaydı. Kapı üzerinde bulunan iki heykel ile içeride bulunan üç adet mezarın üzerindeki insan başı, yazı ve işaretleri içeren kenar taşları müzeye gönderilmek üzere 26 Ekim’de hükümet konağına nakledilmişti. Sonradan yapılan incelemelere göre iç taraftaki mezarlığın altında taştan oyma iki mezarın daha olduğu ortaya çıkmıştı. ${ }^{56}$

29 Haziran 1895 tarihli Sabah gazetesi ise Urfa'daki mahallelerden birinde, inşaat kazısı esnasında bir ibadethane bulunduğundan bahsetmekteydi. ${ }^{57}$ Bidayet mahkemesi azalarından Mahmut Nedim Efendi'nin hususî konağının ${ }^{58}$ inşasında avlu kısmında bir metre kotunda ve on beş santimetre derinliğinde bir değirmen taşı ortaya çıkmıştı. Yapılan tetkikler buranın bir kapı olduğuna işaret etmekteydi. Bir manivela vasıtasıyla açılan yerin, renkli mozaik taşlar ile döşenmiş, altı kişilik bir Süryani aile mezarı olduğuna kanaat getirilmişti. Arkeolojik açıdan ehemmiyeti haiz bulguların nakliyesini bizzat Mahmut Nedim Efendi karşılamıştı. ${ }^{59}$

Batılı uzmanların bölgedeki yoğun incelemeleri ise 1880 sonrası hız kazandı. Filo$\log$ Edward Sachau, 1880 yılının başlarında Balıklı Göl ve çevresindeki bütün kitabe yazılarını kopyalamış ve "Edessenische Inschriften (Edessa Kitabeleri)" adıyla bir makale kaleme almışt1. ${ }^{60} \mathrm{~J}$. E. Gautier' in 1884 'teki Acheuleen tip el baltası keşfi ise net olmamakla birlikte kazı faaliyetleri içerisinde ilkler arasındayd1. ${ }^{61} 20$. yüzyıl başlarında Bağdat demiryolu inşası ve bundan dolayı bölgenin önem kazanması sonucu coğrafya ve topoğrafya araştırmaları fazlalaşmıştı. ${ }^{62}$ Berlin Üniversitesi daimî üyelerinden müzehaneler müdürü Friedrich Delitzsch'in ${ }^{63}$ 1902'deki tarihî tetkikat sahaları arasında Urfa da yer almıştı. ${ }^{64}$ Urfa ve çevresini dolaşan Delitzsch Harran evlerini fotoğraflamış (G. 1), Urfa' daki misyoner yapılarını dolaşmıştı. ${ }^{65}$

56 BOA, MF.MKT. 132/43.

57 BOA, MF.MKT. 272/38.

58 Mahmud Nedim Efendi’nin Dergezenli Mahallesi’ndeki konağı bugün Kurtuluş Müzesi olarak hizmet vermektedir.

59 BOA, MF.MKT. 517/59, 693/9.

60 Remzi Avc1, "Seyahat Notları ve Oryantalist Bilgi Üretimi: Eduard Sachau (1845-1930) Örneği,” Diyalog 8/1 (2020), 42.

61 Ernest Chantre, Recherches Archéologiques Dans l'Asie Occidentale. Mission en Cappadoce 1893-1894 (Paris: Leroux, 1898), 132.

62 Duygu Günay ve Robert Whallon, "Araştırma Bölgesinde Daha Önce Yapılmış İncelemeler ve Geziler", Güneydoğu Anadolu Tarihöncesi Araştırmalarl (İstanbul: İstanbul Üniversitesi Edebiyat Fakültesi Yayınları, 1980), 85 .

63 Alman oryantalist Friedrich Delitzsch (1850-1922) Leipzig'de (1877), Breslau'da (1893) ve 1899'dan itibaren Berlin'de Sami dilleri ve Asuroloji profesörü olarak görev yaptı. Bk. "Delitzsch, Friedrich," 22 Nisan 2020 https://www.encyclopedia.com/religion/encyclopedias-almanacs-transcripts-and-maps/delitzsch-friedrichdeg.

64 Başkanlık Osmanlı Arşivi (BOA), Bâb-1 Ali Evrak Odası (BEO) 1815/136094, 15 Zilhicce 1319 (25 Mart 1902).

65 Friedrich Delitzsch, Im Lande des Einstigen Paradieses (Stuttgart: Deutsche Verlags-Anstalt, 1903), 10, 54-57. 


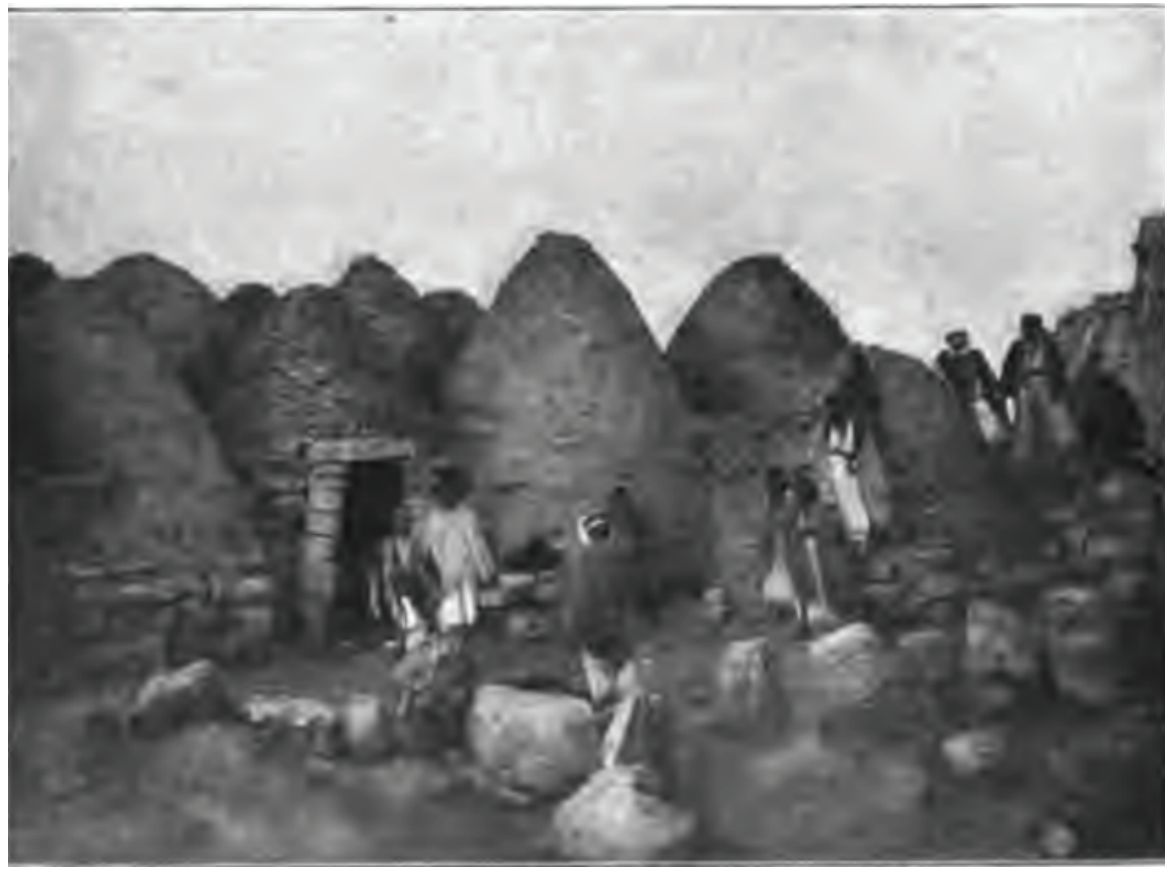

G. 1: Harran evleri, Friedrich Delitzsch, Im Lande des Einstigen Paradieses, 10.

Alman müzecisi ve sanat tarihçisi Friedrich Sarre (1865-1945) ve beraberindeki Alman arkeolog, sanat tarihçisi, Hristiyan ve Bizans sanatları uzmanı Ernst Herzfeld'in 1907'deki seyahat yerleri arasında yine Urfa bulunmaktaydı. Amaçları bölgede bulunan eski eserlerin fotoğraflarını almak ve incelemelerde bulunmakt1. ${ }^{66}$ Ulu Cami'nin bahçesindeki sütun başlıklarını (G. 2) inceleyen Sarre ve Herzfeld ${ }^{67}$, ayrıca kiliseleri ve Urfa Kalesin' deki ${ }^{68}$ yapıları tetkik etmişlerdi. ${ }^{69}$ Mezopotamya seyahatleri esnasında İslami mimarlık eserlerini tespit edip fotoğraflamışlar, bu incelemelerini de I. Dünya Harbi'nden önce Archaeologische Reise im Euphrat und Tigris-Gebiet, Berlin 1911 1920 adıyla dört cilt hâlinde yayımlamışlardı. ${ }^{70}$

669 Aralık 1907 itibariyle Friedrich Sarre ve Ernst Herzfeld'in zararlı bir hareketlerinin görülmediği ve Musul'a azimetleri Zor mutasarrıfı Mehmet Raşid tarafından bildiriliyordu; Başkanlık Osmanlı Arşivi (BOA), İrade- Hariciye (İ.HR) 409/6, 24 Şaban 1325 (2 Ekim 1907); BOA, DH.MKT. 1205/19-1.

67 Friedrich Sarre ve Ernst Herzfeld, Archaeologische Reise im Euphrat und Tigris-Gebiet Band II (Berlin: Dietrich Reimer/Ernest Vohsen A.G, 1920), 15.

68 Sarre ve Herzfeld, Archaeologische Reise im Euphrat und Tigris-Gebiet Band II, 23.

69 Sarre ve Herzfeld, Archaeologische Reise im Euphrat und Tigris-Gebiet Band II, 35.

70 Semavi Eyice, “SARRE, Friedrich,” Türkiye Diyanet Vakfi Íslam Ansiklopedisi, c. 36 (İstanbul: Türkiye Diyanet Vakfi Yayınları, 2009), 165. 


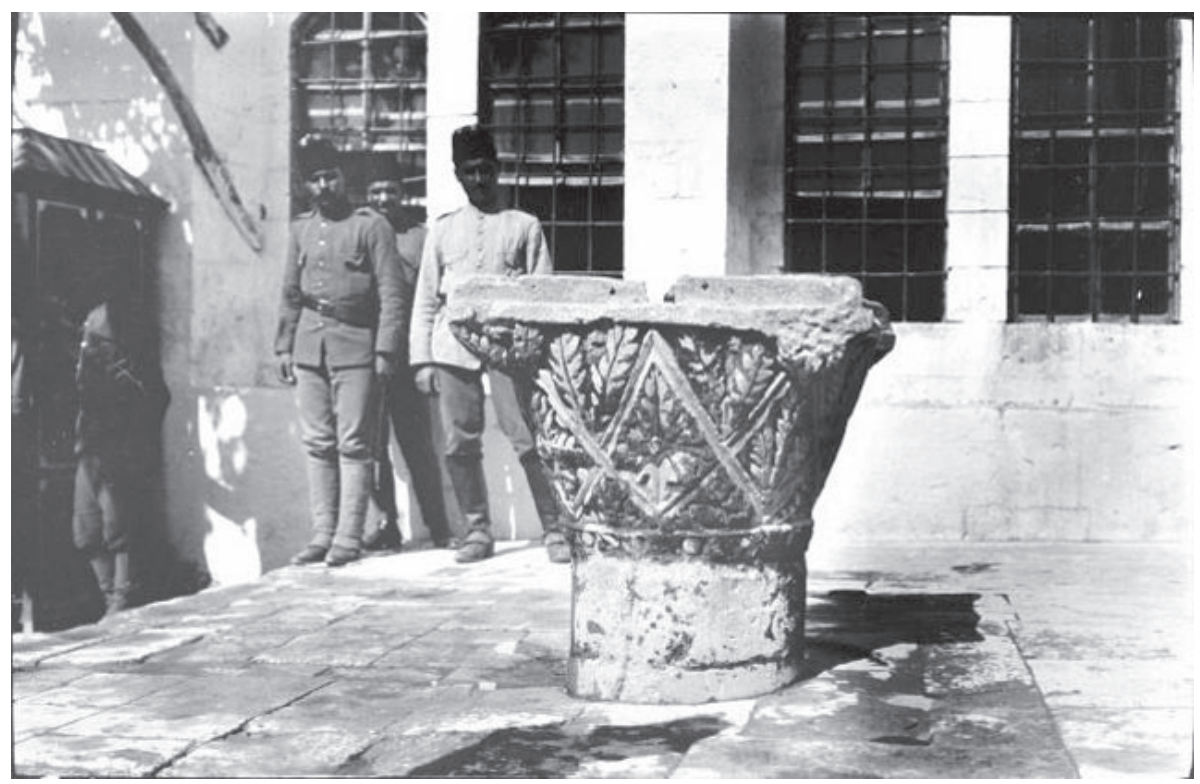

G. 2: Ulu Cami'nin bahçesindeki sütun başlığı,

http://gertrudebell.ncl.ac.uk/photo_details.php?photo_id=6142.

İngiliz Thomas Edward Lawrence da Urfa ve çevresinde kazı yapan öncülerden biriydi. Ehemmiyet arz eden kale, bina ve eski eserleri incelemek üzere Lawrence'ın gideceği mahallerin memurları mütemadiyen uyarılmıştı. ${ }^{71}$ Lawrence 1909 'da Urfa'y1 ziyaret etmişti ancak 1911'deki ziyareti daha çok arkeolojik araştırma amacını taş1maktaydı. $^{72} 14$ Temmuz 1911 Cuma günü Urfa'ya gelen arkeolog kaldığı hana yerleştikten sonra kaleyi fotoğraflamak için dışarı çıkmıştı. Bir gün sonra ise kaleye tırmanmış, birkaç açıdan fotoğraflar almış ve kale içinde ve dışında ölçümler yapmıştı. ${ }^{73}$ Urfa'dan sonraki durağ 1 Harran olan Lawrence buradaki kalede de incelemelerde bulunmuştu. Kalenin birkaç dönemde inşa edilmiş olduğunu belirten Lawrence, Arap öncesi dönemden ziyade daha yakın bir dönemde yapılmış olduğuna işaret etmişti. Daha sonra camiye yönelen Lawrence burada bazalttan bir aslan kabartmasının fotoğrafını çekmişti. ${ }^{74}$ Bilhassa Karkamış kazılarında yer alan Lawrence, bölgede sürekli gezilere çıkıyordu. 1911'de British Museum adına David H. Hogarth ile başlayan Karkamış kazıları, Hogarth'ın Oxford'a dönüşünden sonra Leonard Woolley ve Thomas Edward Lawrence tarafından 1914'e kadar sürdürülmüştï ${ }^{75}$ (G. 3). Lawrence

71 Başkanlık Osmanlı Arşivi (BOA), Dahliye - İdare (DH.ID) 129-1/8, 8 Cemaziyelevvel 1330 (25 Nisan 1912).

72 Thomas Edward Lawrence, Oriental Assembly (Great Britain: Cromwll Press, 2005), 2.

73 Lawrence, Oriental Assembly, 7-12.

74 Lawrence, Oriental Assembly, 13-17.

75 Daha geniş bilgi için bk. Giacomo Benati, “The British Museum Excavations at Karkemish (1911-1914, 1920): A Summary of the Activities and of the Methods Employed," Karkemish An Ancient Capital on the Euphrates, ed. Nicolò Marchetti (Bologna: Ante Quem, 2014), 52-65. 
burada bulunan Hitit dönemine ait çanak-çömlekleri incelemiş ${ }^{76}$ bu süreçte ara ara Urfa'ya da uğramışt1. ${ }^{77}$

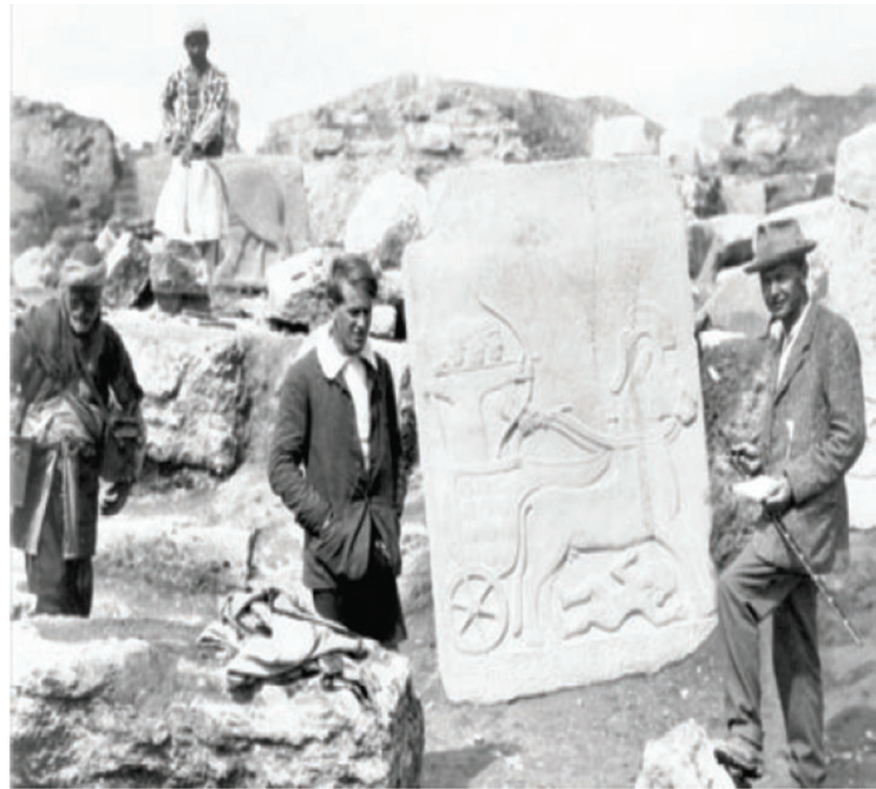

G. 3: Lawrence ve C. L. Woolley Karkamış'ta (1913) (Giacomo Benati, “The British Museum Excavations at Karkemish (1911-1914, 1920): A Summary of the Activities and of the Methods Employed", 54.

Çok iyi surette Arapça bilen, Ortadoğu'daki gezilerini arkeoloji ve tarih öncesi dönem araştırmaları altında yapan Getrude Bell ${ }^{78}$ için Urfa ve çevresi verimli sahalardan biriydi. Bilhassa Hristiyanlık kalıntıları için onu Urfa'ya yönlendiren Max von Oppenheim olmuştu. ${ }^{79} 17$ Mayıs 1911 'de Urfa'ya gelen ${ }^{80}$ Bell $^{81} 18$ Mayıs sabahı ilk incelemelerini Balıklıgöl havzasında yapmaya başlamıştı. Ulu Cami ve Hasan Paşa Camilerini gezdikten sonra Aynzeliha Gölü'nün yanındaki bir kahvehaneye oturmuş ve kaleden fotoğraflar almıştı. ${ }^{82}$ Mektuplarında Balıklıgöl'deki camiyi ve servi ağaçlarını Türkiye'de gördüğü en güzel yerlerden biri olarak tasvir etmişti. (G. 4). Bell, Bağdat demir yollarının inşasından sorumlu mühendis Meissener Paşa (Heinrich Au-

76 D. G. Hogarth, Hittite Problems and the Excavation of Carchemish (London: Published fort he British Academy, 1911), 10.

77 Lawrance, Urfa'daki bir kahvehanede gece yarısı oynanan ucuz bir tiyatrodan dolayı (amatörce sergilenen bir oyun olmalı) uyuyamadığını aktarır: Lawrence, Oriental Assembly, 7; İsmail Asoğlu, "Osmanlı Urfası'nda Kahve, Kahvehaneler ve Müdâvimleri," History Studies 13/1 (2021), 106.

78 Gertrude Bell-Mektup ve Günlük Arşivi için bk. http://gertrudebell.ncl.ac.uk/ erişim 1 Ocak 2022.

79 “28 Ocak 1909 tarihli günlük,” erişim 18 Şubat 2021, http://gertrudebell.ncl.ac.uk/diary_details.php?diary_id=655.

80 “17 Mayıs 1911 tarihli günlük," erişim 26 Mart 2021, http://gertrudebell.ncl.ac.uk/diary_details.php?diary_id=989.

81 Getrude Bell'in Ortadoğu sahasındaki faaliyetleri için bk. Taha Niyazi Karaca, Sınırları Çizen Kadın Ingiliz Casus Gertrude Bell (İstanbul: Kronik Yayınları, 2019).

82 “18 Mayıs 1911 tarihli günlük,” erişim 18.02.2021, http://gertrudebell.ncl.ac.uk/diary_details.php?diary_id=991. 
gust Meissner) ile Urfa'da karşılaşmıştı. ${ }^{83} 19$ Mayıs sabahı ise Karkamış ve Cerablus sahasında kazı yapan David George Hogarth’1 görmek üzere Birecik'e doğru yola çıkmışt1. ${ }^{84}$ Ancak Hogarth, Oxford'a döndüğünden Bell, burada Hogarth'ın yerine geçen yardımcısı Campbell Thompson ve Lawrence ile tanışma firsatı bulmuştu. ${ }^{85}$

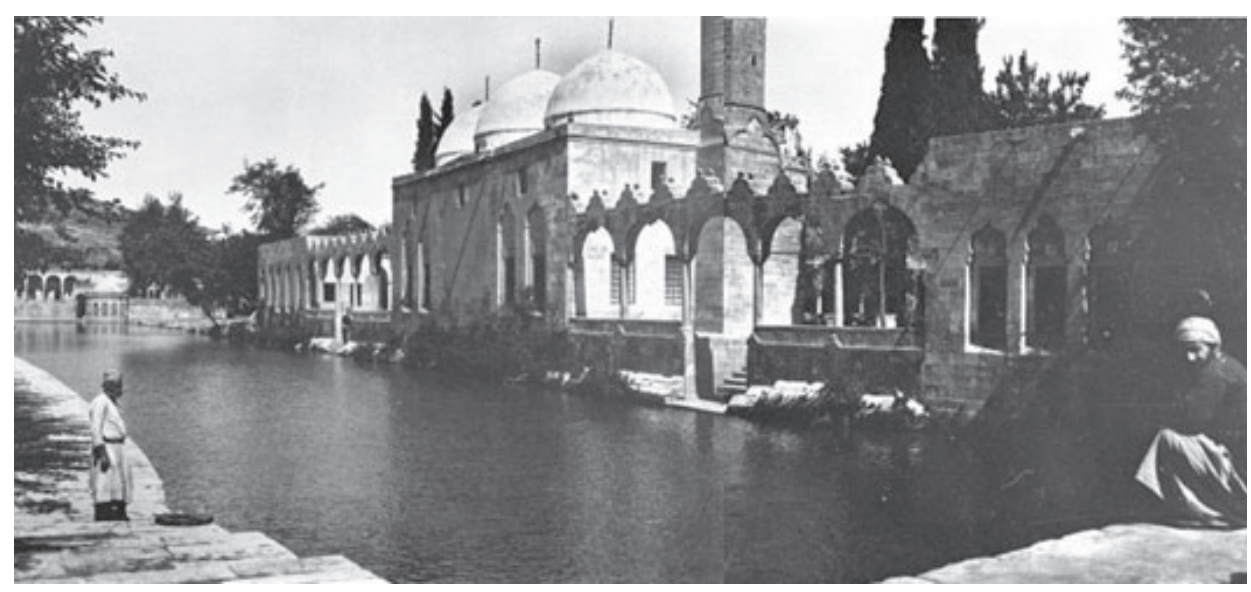

G. 4: Bell'in arşivinden Urfa - Balıklıgöl,

http://gertrudebell.ncl.ac.uk/photo_details.php?photo_id=6143

1893, 1899 ve 1911 yıllarında yaptığı araştırma gezilerinden Urfa ve çevresinden çok zengin epigrafik malzeme toplayan ${ }^{86}$ Max von Oppenheim'ın bölgeye ve çevresine karşı ilgisinin arka planı, Almanya'nın geç kaldığı sömürge yarışında var olma çabası ile ilişkiliydi. Bir tarih yazımı içerisinde, o güne kadar eşi benzeri olmayan bir propaganda ve strateji çalışmaları icra edildi. Bu büyük ideal için edebiyattan arkeolojiye, radyo programlarından tiyatro ve sinemaya, gazetelerden karikatüre kadar her şey araçsallaştırılmıştı. ${ }^{87} 1911$ 'deki bilimsel seyahatinde, tarafına hürmet edilmesi, fotoğraf alımlarına müsaade edilmesi için Beyrut, Suriye, Halep, Diyarbakır, Adana, Musul, Bağdat ve Basra vilayetleri bilgilendirilmişti. ${ }^{88}$ Ancak Oppenheim'ın siyasi emellerini anlayacak ve bilgi sağlayacak bir iki memurun ona eşlik etmesi isteniyordu ${ }^{89}$

83 “20 Mayıs 1911 tarihli mektup,” erişim 23.04.2021,

http://gertrudebell.ncl.ac.uk/letters.php?year=1911\&month=5; ayrıca bk. Karaca, Sinırları Çizen Kadın Ingiliz Casus Gertrude Bell, 148.

84 “14 Mayıs 1911 tarihli mektup," erişim 23 Nisan 2021,

http://www.gerty.ncl.ac.uk/letter_details.php?letter_id=1825. Ayrıca bk. Zuhal Özel Sağlamtimur, "Batılı Seyyahların Fotoğraflarında Urfa," Harran ve Çevresi Arkeoloji, ed. Mehmet Önal, Süheyla İrem Mutlu ve Semih Mutlu (Şanlıurfa: Elif Matbaas1, 2019), 580-581.

85 Daha geniş bilgi için bk. The Letters of T.E Lawrence, ed. David Garnett (Londan: Alden Press, 1938), 104106; Karaca, Sinırları Çizen Kadın Ingiliz Casus Gertrude Bell, 148-151.

86 Duygu Günay ve Robert Whallon, “Araştırma Bölgesinde Daha Önce Yapılmış İncelemeler ve Geziler”, 87.

87 İbrahim Sarıtaş, “Alman İmparatorluğu’nun Türk Dünyasına Yönelik Propaganda Faaliyetleri: Arkeolog Max Freiherr von Oppenheim ve Doğu Haber Ajansı," Bilig - Türk Dünyast Sosyal Bilimler Dergisi 91 (2019), 114.

88 BOA, DH.ID: $129-2 / 1-2$.

89 BOA, DH.ID: $129-2 / 1-5$. 
çünkü araştırmacılara fonlamayı Avrupalılar sağladığı ve çalışmaları onlar yürüttüğü hâlde, Osmanlı memurlarının gözetiminde olmak zorundaydılar. ${ }^{90}$ Her şeye rağmen Halep Valisi Hüseyin Kâzım, bölgedeki hareketlilikten oldukça rahatsızdı ve hükümetin ehemmiyetsiz tavrına anlam verememekteydi. Oppenheim'ın siyasi maksat içerisinde olduğundan emindi. Bedeviler arasında fesatlık yaratacağından, yanına birkaç jandarma verilmesini yeterli görmemişti. Bu kadar önemli bir meselede arkeoloğun hareketlerini takip edecek, varlığıyla cüretini kıracak, lisana aşina bir memur tayin edilmesini istemişti. Valiye göre mesele memleketin hayatî menfaatleriyle ilişkiliydi. Anlama kabiliyetini haiz bir zatın vakit kaybetmeden memur edilmesi, memleketin selameti namınayd1 ${ }^{91}$ Fakat I. Dünya Harbi'nden öncesine değin bölgedeki Alman bilim adamlarının araştırmaları aralıklarla devam etti. 1913 yılı içerisinde Alman arkeolog Rudolf Berliner, benzer şekilde Almanya'nın Münih şehri kütüphane müdürü şark uzmanlarından Dr. Emil Gratzl'ın araştırma sahaları içerisinde Urfa da yer almaktaydı. ${ }^{92}$

Kazı alanları, civar ahali, arkeologlar ve hükümet yetkilileri arasında mülkiyet hakk1 ya da toprak tasarrufuna dayalı sorunlar yaratabilmekteydi. Kazılarda muhafaza ve sevk olunacak eski eserler için hane veyahut ambar gibi yerlerin inşası da benzer sorunlara kapı aralamaktaydı. Osmanlı bu tür yapıların kazı ekibince inşa edilmesinden yanaydı. Aksi takdirde hükümetin yapma mecburiyeti doğuyordu. ${ }^{93}$ Arazinin mülkiyet durumu kazının sürekliliği açısından önemliydi. Yerli tasarruf sahipleri ise asar-1 atika nizamnamesinin maddelerinden haberdard1. "Arazisi üzerinde araştırmaya lüzum görüldüğ̈̈nde mülk sahibinin razı edileceğini" "94 öne sürerek ödeme bekliyorlardı.

Farklı medeniyetlerden tevarüs eden dinsel geçmişiyle Urfa şehrinin mabetler tarihi de ayrı bir yere oturtulmalıdır. Çok katmanlı bir geçmişe sahip çeşitli Anadolu şehirleri gibi farklı dönemlerdeki sakinlerince çeşitli derecelerde kutsallık atfedilmiş olan pek çok mabede Urfa ev sahipliği etmiştir. ${ }^{95}$ Her dinden insan, inançlarını şahsî kimliklerinin ana unsuru sayıyor ve aralarındaki din temelindeki farklılığı kabulleniyordu. ${ }^{96}$ Ancak imparatorluğun son yarım yüzyılında farklı dinlere mensup şehir sakinlerinin tarihî yapılar üzerindeki hak iddiaları, eski yapıların onarımlarına gösterilen ehemmiyet, bulguların sahiplenilme çabası sadece Müslümanlar ve Hristiyanlar arasinda bir rekabet yaratmadi. Ermeniler ve Süryaniler arasında, tarihî kiliseler ve mezarlıklar üzerinden yaşanan mezhep kaynaklı ihtilaflar bu süreçte daha da derinleşti.

90 Çelik, Asar-ı Atika - Osmanlı İmparatorluğu'nda Arkeoloji Siyaseti, 12.

91 BOA, DH.İD. 129-2/1-11-12.

92 BOA, DH.İ. 28/18, 28/23.

93 BOA, DH.ID. 129-1/8-9.

9422 Mart 1911'de Meclis idare azasından İsmail Hilmi ve tapu kâtibi namına Dikran Lütfi Efendiler karye-i mezkûra gittiler. Hafriyat icra olunan mülk, müsted 'inin yedindeki tapuya dahil olduğu, edinilen tedkikat ve tahkikattan anlaşılmakla rapor tanzim ve takdim kılındı; BOA, DH.İD. 129-1/8-17.

95 A. Hilal Uğurlu ve Suzan Yalman, Kutsal Mekânlar ve Kentsel Ağlar (İstanbul: Anamed, 2019), 7.

96 Abraham Marcus, Modernliğin Eşiğinde Bir Osmanlı Şehri Halep, çev. Mehmet Emin Taş (İstanbul: Küre Yayınları, 2013), 62. 
II. Abdülhamid devrindeki imarlaşma, çevresel değişim, şehirdeki tadilata muhtaç camilerin onarımları da aslında bir siyasetin parçasıydı. Tarihî Ömeriye Camii’nin (inş. 634-644) 1895 'teki tadilatı, İslâm mirasını görünür kılmak adına yapılmıştı. Bu tutum ayrıca, sultanın İttihad-1 İslam siyasetiyle uyumlu olarak, o güne kadar ihmal edilmiş Doğu topraklarına doğru resmî dönüşün mesajını barındırmaktayd $1 .{ }^{97} \mathrm{Bu}$ doğrultuda Mühendis Ali Sami Efendi ile iki Ermeni mimar ustasına bir keşif raporu hazırlatılmışt. ${ }^{98}$ Tarihî İslamî yapıların onarımı ile birlikte Osmanlı Devleti'nin şanı ve kudretini doğrudan yansıtan kamusal yapılara konan armalar, ${ }^{99}$ yapısal ihtiyaçların yanı sıra siyasi gerekliliklerdendi. ${ }^{100}$ Sultanın egemenliğinin şehirdeki ilk görsel teyidi ${ }^{101}$ Urfa Hamidiye Hastahanesi'nin (Millet Hastanesi) cephesine yerleştirilen Osmanlı arması olmuştu. Tarihî kiliselerin onarım ve yeniden inşaları, bilhassa 1slahat fermanı (1856) sonrasında Hristiyan tebanın yapısal faaliyetlerindeki hız ve dönüşümle de ilgiliydi. Zira ibadet yeri kültürel bir değere sahipti. Kültürün dinî uygulamalarını ve inançlarını sürdürme becerisine katkıda bulunuyordu. 1899'da Meryem Ana Kilisesi'nin asli hâline dönüştürme çabası da tarihî süreklilik içerisinde, şehirdeki Ermeni varlığını simgeleyen bir yapıyı ayakta tutmak ve devamlılığını sağlamak içindi. ${ }^{102}$

Hıdır İlyas Manastırı (G. 5) üzerinde Süryani ve Ermeni sakinlerin hak iddiaları ise her ne kadar iki toplum arasında yaşanan mezhep ihtilafına dayansa da esasında cemaat üyelerinin kendileri için kültürel açıdan önemli bir yere sahip olmak çabas1 ile ilgiliydi. ${ }^{103}$ Tarihî ibadet yeri ve çevresindeki mezarlıklar; aidiyetin, kimliğin ve en önemlisi şehirdeki uzun süreli varlı̆̆ kanıtlayan yerler arasındaydı. Muhtelif zamanlarda ve çeşitli milletlerden seyyahların dikkatini çeken manastıra Ermeni ve Süryani sakinler inanç, mimari ve muhit açısından değer atfediyordu. Manastır ve çevresindeki mezarlıklar Hristiyan geçmişin izlerini barındırmaktaydı. Aslında mabet bir anlatı içerisinde, belirli mekânların "kutsal" statüye yükseltilmiş ${ }^{104}$ örneklerinden biriydi. Hıdır İlyas ya da Hızır İlyas anlatısı pek çok inanışta yer edinmişti. ${ }^{105}$ Aziz

97 Çelik, Asar-ı Atika - Osmanlı İmparatorluğu’nda Arkeoloji Siyaseti, 21.

98 BOA, ŞD: 135/80.

99 Selim Deringil, İktidarın Sembolleri ve İdeoloji II. Abdülhamid Dönemi (1876-1909), çev. Gül Çağalı Güven (İstanbul: Doğan Kitap, 2014), 34.

100 A. Hilal Uğurlu, "Müceddid" Osmanlı Sultanı III. Selim'in Siyasi Söyleminde "Kutsalların” Rolü (h. 17891807)," Kutsal Mekânlar ve Kentsel Ağlar (İstanbul: Anamed, 2019), 105-106.

101 Deringil, Ikktidarın Sembolleri ve İdeoloji II. Abdülhamid Dönemi (1876-1909), 43.

102 İsmail Asoğlu, "Birliktelikten Yol Ayrımına Urfa Kazasında Gayrimüslimler," (Doktora tezi, Harran Üniversitesi, 2019), 56.

103 James O. Young, "The Values of the Past", Appropriating the Past: Philosophical Perspectives on the Practice of Archaeology, ed. Geoffrey Scarre ve Robin Coningham (Cambridge: Cambridge University Press, 2012), 34 .

104 Uğurlu ve Yalman, Kutsal Mekânlar ve Kentsel Ağlar, 5.

105 İslâm ve diğer inanışlardaki "Hızır" ya da "Hıdır" telâkkisine için bk. İlyas Çelebi, Süleyman Uludağ ve Cemal Kurnaz, "Hızır," TDV İslam Ansiklopedisi, c. 17 (İstanbul: Türkiye Diyanet Vakfı Yayınları, 1998), 406-212. 
Efraim'in ${ }^{106}$ mezarının manastırın altında olduğu iddiası ise yine bir anlatı içerisinde mekânın kutsallaşmasını sağlamıştı. Hürmet edilen aziz mezarının burada olduğu düşüncesi kutsal bir çevrenin inşasında etkili olmuştu. ${ }^{107}$ Manastır ve altındaki mezarlar, Hristiyan sakinlerce sembolik değere sahipti ve ayrıca işlevseldi. Burası, ölen kişinin anısı için kült yeri, yaşayanlar ve ölüler arasında bir etkileşim yeri hâline gelmişti. ${ }^{108}$ Mabet ve mezarlıklar üzerinde iki cemaat arasında yaşanan çekişme Urfa kadısının kararıyla bir süreliğine çözüme kavuşturulmuştu.

Tarafların esas gayesi manastır ve mezarların kendi cemaatlerine ait olduğuna delil sayılacak resmî bir evrakı Osmanlı mahkemesinden alabilmekti. ${ }^{109} 17$. yüzyılın ortalarında şehri ziyaret eden seyyah Tavernier'e göre Hıdır İlyas Kilisesi, Aziz Efraim tarafından yaptırılmıştı. Aslında manastır Aziz Sarkis'e (Surp Sarkis) adanmıştı ama Müslümanların saygı ve hoşgörülerini kazanabilmek adına Hıdır İlyas adı verilmişti. George Percy Badger, burada sekiz mezar olduğunu ve bunların en büyüğünde Aziz Efraim'in yattığını nakletmişti. Ayrıca Süryaniler nazarında mabedin önemli oluşunu Aziz Efraim'in burada yatıyor oluşuna bağlamaktayd. ${ }^{110}$ Mabet ve çevresindeki mezarlara Süryaniler tarafından müdahale esasen iki millet arasındaki mezhep kaynaklı bir mesele iken ${ }^{111}$ müşterek kimlik ve kutsal geçmişe ulaşma konusunda da Ermeniler ile kıyasıya devam eden kültürel bir savaş söz konusuydu. ${ }^{112}$

106 Tarihi kesin olmamakla birlikte Aziz Efraim'in miladî 285 ’te doğduğu ileri sürülür. 303’te, doğduğu şehir olan Nusaybin'den ayrılarak Urfa'ya yerleştiği bilinmektedir. 4. yüzyılın en üretken ruhani yazarlarından biridir. 4. yüzyılın başında Nusaybin'de kurulan akademide eğitim alan Aziz Efraim gibi öğrenciler sayesinde ilim faaliyetleri dünyaya yayılmıştır. Bk. Michel Van Esbroeck, "Ephraem Syrus, Saint," Coptic Encyclopedia, c. 3 (New York: Macmillan Publishing, 1991), 963. Ahmet Kütük, "Nusaybinli Aziz Yakub ve Nusaybin Şehrinin Manevi Savunması (M.S. 338-350)", Mukaddime 5 (2012), 20; Gabriyel Akyüz, Kilise Ataları Tarafindan "Kutsal Ruh'un Kavalı Olarak Adlandırllan Süryani Mor Efrem 'in Şiirleri (Ankara: Kültür ve Turizm Bakanlı̆̆1 Yayınları, 2012), 7.

107 Uğurlu ve Yalman, Kutsal Mekânlar ve Kentsel Ağlar, 6.

108 Dominik Bonatz, "Syro-Hittite Funerary Monuments Revisited", Dining And Death: Interdisciplinary Perspectives On The 'Funerary Banquet' In Ancient Art, Burial And Belief, ed. Catherine Mary Draycott ve Maria Stamatopoulou (Leuven: Peeters, 2016), 177.

109 Başkanlık Osmanlı Arşivi (BOA), Şer ‘iyye Sicil Defterleri (MŞH.ŞSC.d) 8829/117-1384.

8 Rebiülevvel 1291 (25 Nisan 1874).

110 Badger, The Nestorians and Their Rituals: with the Narrative V. 1, 327-328.

111 Başkanlık Osmanlı Arşivi (BOA), Şura-yı Devlet (ŞD) 2416/20, 18 Safer 1296 (11 Şubat 1879). BOA, ŞD. $2447 / 31$.

112 Bernhard Giesen ve Kay Junge, "Tarihsel Hafiza," Tarihsel Sosyoloji Temeller ve Tartı̧malar, haz. Gerard Delanty ve Engin F. Işın, çev. Ümit Tatlıcan (İstanbul: Islık Yayınları, 2017), 528. 


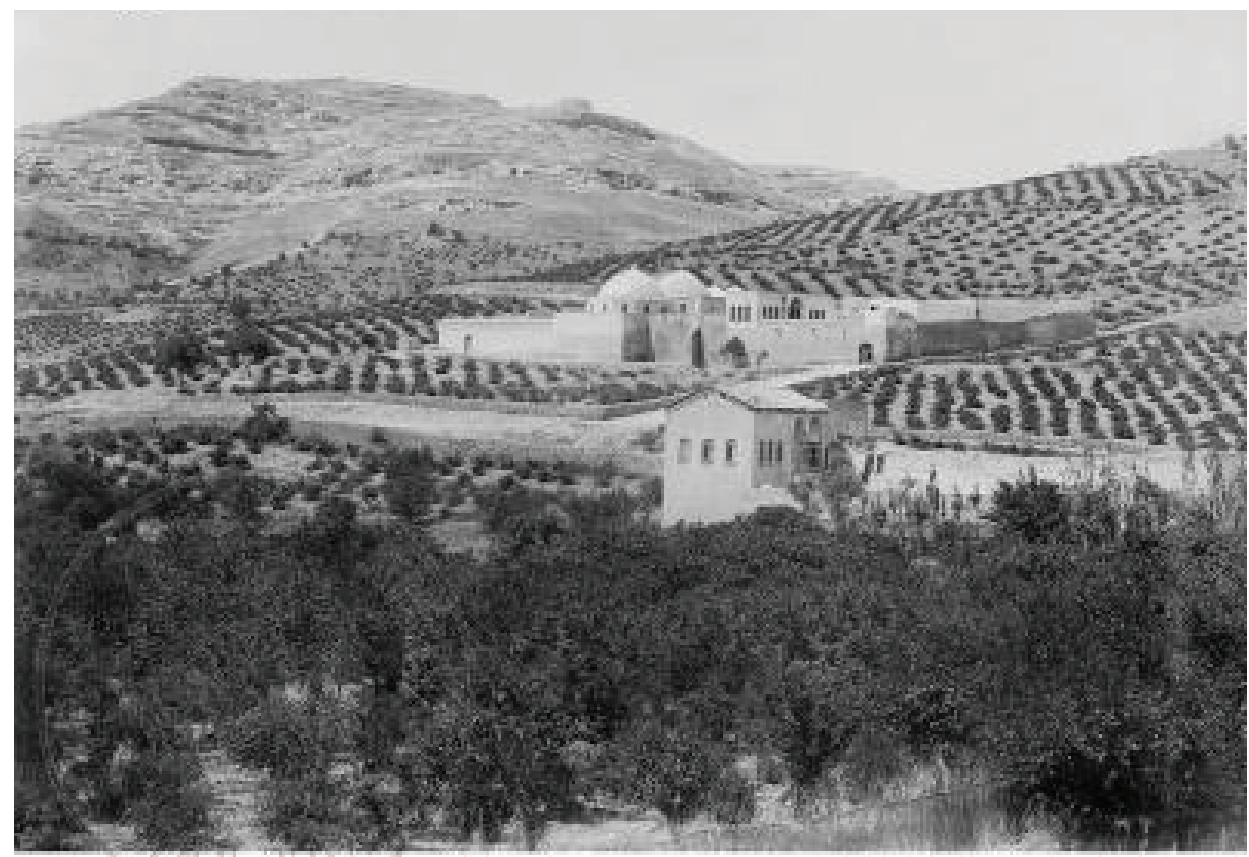

Sig. Oppenheim 10/6 S.64

G. 5: Hidır İlyas Manastır1,

http://ancientworldonline.blogspot.com/2012/06/max-von-oppenheim-photo-collection.html

\section{Sonuç}

Osmanlı Devleti'nin arkeoloji alanına ilişkin icraatları, Urfa gibi merkezden uzak bölgelerde çok fazla uygulama alanı bulamadı. İdarecilerin alana münhasır bilgiye sahip olamayışı ve buluntuların Dersaadet'e taşınamayacak durumda oluşu bunda etkili oldu. 20. yüzyılın başlarında kale taşlarının satışı için gereken izinlerin verilmiş olması, tarihî eserlere karşı hassasiyet bilincinin henüz gelişmemiş olduğunun göstergesiydi. Urfa idarecilerinin yapı ve buluntulara karşı tasarrufu, dönemlere göre farklılık göstermesi, böyle bir hassasiyetin oluşmaya başladığının işareti olarak kabul edilebilir. Nitekim kazı masraflarının zaman zaman Urfa belediyesince karşılanmış olması veyahut Mahmut Nedim Efendi gibi seçkinlerin bulguların nakli için ekonomik destek sağlaması az da olsa arkeolojiye, tarihî eserlere karşı bir farkındalığa işaretti.

Osmanlı üzerindeki dış baskının yoğun olduğu bir dönemde, Batılı mütehassısların arkeolojik araştırma adı altında yürüttükleri siyasi faaliyetler, yeni bir sömürgeci yayılım şekliydi. Bu sebeple Gertrude Bell, Thomas Edward Lawrence gibi İngiliz ajanların, Max von Oppenheim gibi Alman diplomatların arkeolog kimliğiyle Urfa çevresindeki araştırmaları, Urfa idarecilerinin yönetebilme erkini, I. Dünya Harbi’ne 
kadar sınayan sorunların başında geldi. Alman filolog ve şarkiyatçı Edward Sachau, Alman müzecisi ve sanat tarihçisi Friedrich Sarre, Alman arkeolog Rudolf Berliner, Alman Şark bilginlerinden Dr. Emil Gratzl gibi uzmanların şehir ve çevresindeki yoğun incelemeleri, bölgenin arkeolojik açıdan verimli bir saha olduğunun Batılı uzmanlarca uzun süredir bilindiğini göstermekteydi.

Kimliklerin ve toplumsal ilişkilerin yeniden tanımlandığı bir çağda, Müslüman ve Hristiyan sakinler için tarihî cami ve kiliseler, birer ibadet merkezinden daha fazlasinı ifade etti. Berlin Muahedesi'nin (1878) Ermeniler lehine kararları sonrası Urfa Ermenileri iç dayanışmalarına daha fazla yönelim gösterdi. Bu tarih sonrası, kimliği ve varlığı simgeleyen Hıdır İlyas Manastırı ve çevresindeki mezarlıklar gibi tarihî yapılara sahip oluş, mezhep ve kimlik siyasetinin bir parçası hâline getirildi. Buna karşılık, Bâbali'nin de desteğiyle Müslüman cemaat ise tarihî İslamî yapıları görünür kılmak adına onarımlara yöneldi.

Hakem Değerlendirmesi: Dış bağımsız.

Çıkar Çatışması: Yazar çıkar çatışması bildirmemiştir.

Finansal Destek: Yazar bu çalışma için finansal destek almadığını beyan etmiştir.

Peer-review: Externally peer-reviewed.

Conflict of Interest: The author has no conflict of interest to declare.

Grant Support: The author declared that this study has received no financial support.

\section{Kaynakça/References}

Akçura, Necva. "Türkiye ve Eski Eserler.” Mimarlık Dergisi 8 (1972): 39-42.

Akyüz, Gabriyel. Kilise Ataları Tarafindan “Kutsal Ruh'un Kavalı Olarak Adlandırılan Süryani Mor Efrem 'in Şiirleri. Ankara: Kültür ve Turizm Bakanlığı Yayınları, 2012.

Asoğlu, İsmail. Birliktelikten Yol Ayrımına Urfa Kazasında Gayrimüslimler. Doktora tezi, Harran Üniversitesi, 2019.

Asoğlu, İsmail. “Osmanlı Urfası'nda Kahve, Kahvehaneler ve Müdâvimleri.” History Studies 13/1 (2021): 99-112.

Atasoy, Sümer. “Türkiye'de Müzecilik.” Cumhuriyet Dönemi Türkiye Ansiklopedisi VI (1984): $1458-1471$.

Avc1, Remzi. "Seyahat Notları ve Oryantalist Bilgi Üretimi: Eduard Sachau (1845-1930) Örneği”, Diyalog 8/1 (2020): 29-47.

Badger, George Percy. The Nestorians and Their Rituals: with the Narrative V. 1. London: J. Masters and Co. Printers, 1852.

Baram, Uzi ve Lynda Caroll. Osmanlı Arkeolojisi. İstanbul: Kitapyayınevi, 2004.

Bell, Getrude, “28 Ocak 1909 tarihli günlük.” Erişim 18 Şubat 2021. http://gertrudebell.ncl.ac.uk/ diary_details.php?diary_id=655.

Bell, Getrude, “17 Mayıs 1911 tarihli günlük.” Erişim 26 Mart 2021. http://gertrudebell.ncl.ac.uk/ diary_details.php?diary_id=989. 
Bell, Getrude, “14 Mayıs 1911 tarihli mektup.” Erişim 23 Nisan 2021. http://www.gerty.ncl.ac.uk/ letter_details.php?letter_id=1825.

Bell, Getrude, “20 Mayıs 1911 tarihli mektup.” Erişim 23 Nisan 2021. http://gertrudebell.ncl.ac.uk/ letters.php?year=1911\&month $=5$.

Benati, Giacomo. "The British Museum Excavations at Karkemish (1911-1914, 1920): A Summary of the Activities and of the Methods Employed." Karkemish An Ancient Capital on the Euphrates. Ed. Nicolò Marchetti. (Bologna: Ante Quem, 2014), 52-65.

Bonatz, Dominik. "Syro-Hittite Funerary Monuments Revisited", Dining And Death: Interdisciplinary Perspectives On The 'Funerary Banquet in Ancient Art, Burial And Belief. Ed. Catherine Mary Draycott ve Maria Stamatopoulou. Leuven: Peeters, 2016, 173-193.

Brijder, Herman A. G. "Other Expeditions and Discoveries, in the Later $19^{\text {th }}$ Century." Nemrud Dağl (Recent Archaeological Research and Preservation and Restoration Activities in the Tomb Sanctuary on Mount Nemrud). Berlin: De Gruyter, 2014, 184-232.

Bruneau, Michel. Küçük Asya'dan Türkiye 'ye Azınlıklar, Etnik-Milli Homojenleştirme, Diasporalar. İstanbul: İletişim Yayınları, 2018.

Buckingham, James Silk. Travels in Mesopotamia. London: Printed by D. S. Maurice, 1827.

Chantre, Ernest. Recherches Archéologiques dans l'Asie occidentale. Mission en Cappadoce 18931894. Paris: Leroux, 1898.

Chesneys, Francis Rawdon. Narrative of the Euphrates Expedition 1835, 1836 and 1837. London: Printed by Spottiswoode \& Co, 1868.

Çelebi, İlyas. Uludağ Süleyman ve Cemal Kurnaz. "Hızır." Türkiye Diyanet Vakfi İslam Ansiklopedisi. C. 17. İstanbul: Türkiye Diyanet Vakfı Yayınları, 1998, 406-212.

Çal, Halit. “Osmanlı Devletinde Âsâr-1 Atîka Nizamnâmeleri.” Vakıflar Dergisi 26 (1997): 391-400.

Çelik, Zeynep. Asar-ı Atika - Osmanlı İmparatorluğu'nda Arkeoloji Siyaseti. İstanbul: Koç Üniversitesi Yayınları, 2016.

Çoker, Adnan. Osman Hamdi ve Sanay-i Nefise Mektebi. İstanbul: Mimar Sinan Üniversitesi Yayınlar1, 1983.

“Delitzsch, Friedrich.” Erişim 22 Nisan 2020.

https://www.encyclopedia.com/religion/encyclopedias-almanacs-transcripts-and-maps/delitzschfriedrichdeg.

Delitzsch, Friedrich. Im Lande des Einstigen Paradieses. Stuttgart: Deutsche Verlags - Anstalt, 1903.

Deringil, Selim. İktidarın Sembolleri ve İdeoloji II. Abdülhamid Dönemi (1876-1909). Çev. Gül Çağalı Güven. İstanbul: Doğan Kitap, 2014.

Diaz-Andreu, Margarita. A World History of Nineteenth-Century Archaeology: Nationalism, Colonialism, and the Past. Oxford: Oxford University Press, 2008.

Ekinci, Abdullah. Müze Şehir Urfa. Ankara: Şanlıurfa İl Kültür ve Turizm Müdürlüğü Yayınları, 2006.

Ekinci, Abdullah. Ortaçağda Urfa - Efsane, Tarih, İnanç, İlim ve Felsefe. Ankara: Gazi Kitabevi, 2006.

Ekinci, Abdullah. Şanlıurfa and Harran. Ankara: Republic of Turkey Ministry of Culture and Tourism Directorate General of Libraries and Publications, 2015. 
Eldem, Edhem. "Osman Hamdi Bey'in Bağdat Vilâyeti'ndeki Görevi Sırasında Babası Edhem Paşa'ya Mektupları." 1. Osman Hamdi Bey Kongresi Bildiriler 2-5 Ekim 1990. Haz. Zeynep Rona. İstanbul: Mimar Sinan Üniversitesi Yayınları, 1992, 65-98.

Eldem, Edhem. Le Voyage à Nemrud Dă̆ı d'Osman Hamdi Bey et Osgan Efendi (1883). Paris: De Boccard, 2010.

Eldem, Edhem. Un Ottoman En Orient Osman Hamdi Bey en Irak, 1869-1871. Paris: Actes Sud, 2010.

Eldem, Edhem. "An Ottoman Traveler to the Orient Osman Hamdi Bey." Poetics and Politics of Place Ottoman Istanbul and British Orientalism. Der. Zeynep İnankur, Reina Lewis ve Mary Roberts. İstanbul: Pera Müzesi, 2011.

Eldem, Edhem. Mitler, Gerçekler ve Yöntem Osmanlı Tarihinde Aklıma Takılanlar. İstanbul: Tarih Vakfi Yurt Yayınları, 2018.

Esbroeck, Michel Van. “Ephraem Syrus, Saint.” Coptic Encyclopedia. Vol. 3. New York: Macmillan Publishing, 1991, 963.

Eyice, Semavi. “Arkeoloji Müzesi ve Kuruluşu.” Tanzimat 'tan Cumhuriyet'e Türkiye Ansiklopedisi. C. 6. İstanbul: İletişim Yayınları, 1985, 1596-1699.

Eyice, Semavi. "SARRE, Friedrich.” Türkiye Diyanet Vakıf İslam Ansiklopedisi. C. 36. İstanbul: Türkiye Diyanet Vakfı Yayınları, 2009, 165-166.

Giesen, Bernhard ve Kay Junge. "Tarihsel Hafıza.” Tarihsel Sosyoloji Temeller ve Tartışmalar. Haz. Gerard Delanty ve Engin F. Işın. Çev. Ümit Tatlıcan. İstanbul: Islık Yayınları, 2017, 523-539.

Günay, Duygu ve Robert Whallon. “Araştırma Bölgesinde Daha Önce Yapılmış İncelemeler ve Geziler.” Güneydoğu Anadolu Tarihöncesi Araştırmaları. İstanbul: İstanbul Üniversitesi Edebiyat Fakültesi Yayınları, 1980, 83-106.

Gündüz, Filiz. “Osman Hamdi Bey.” Türkiye Diyanet Vakfi İslam Ansiklopedisi. C. 33. Ankara: Türkiye Diyanet Vakıf Yayınları, 2007, 468-469.

Habermas, Jürgen. “Öteki” olmak, “Öteki” İle Yaşamak. Çev. İlknur Aka. Yapı Kredi Yayınları: İstanbul 2012.

Hogarth, D. G. Hittite Problems and the Excavation of Carchemish. London: Published fort he British Academy, 1911.

Lawrence, Thomas Edward. Oriental Assembly. Great Britain: Cromwll Press, 2005.

The Letters of T.E Lawrence. Ed. by David Garnett. Londan: Alden Press, 1938.

Traveller. "Vandalism in Upper Syria And Mesopotamia." Times. 9 Ağustos 1911.

Karaca, Taha Niyazi. Sinırları Çizen Kadın İngiliz Casus Gertrude Bell. İstanbul: Kronik Yayınları, 2019.

Kurat, Yuluğ Tekin. Henry Layard'ın İstanbul Elçiliği, 1877-1880. Ankara: Ankara Üniversitesi Dil ve Tarih-Coğrafya Fakültesi Yayınları, 1968.

Kütük, Ahmet. "Nusaybinli Aziz Yakub ve Nusaybin Şehrinin Manevi Savunması (M.S. 338-350)." Mukaddime 5 (2012): 1-24.

“Le Musée Imperial.” La Turquie. 5 Juin 1883. Erişim 4 Nisan 2021, https://archives.saltresearch. org/handle/123456789/129158.

Mansel, Arif Müfid. “Osman Hamdi Bey.” Belleten XXIV/94 (1960): 291-301.

Marcus, Abraham. Modernliğin Eşiğinde Bir Osmanlı Şehri Halep. Çev. Mehmet Emin Taş. İstanbul: Küre Yayınları, 2013. 
Moltke, Helmuuth Von. Moltke'nin Türkiye Mektupları. Çev. Hayrullah Örs. İstanbul: Remzi Kitabevi, 2017.

Mumcu, Ahmet. "Eski Eserler Hukuku ve Türkiye.” Ankara Üniversitesi Hukuk Fakültesi Dergisi XXVI/3-4 (1969): 65-66.

Ortayl1, İlber. “Tanzimat'ta Vilayetlerde Eski Eser Taraması.” Tanzimat'tan Cumhuriyet'e Türkiye Ansiklopedisi. C. 6. İstanbul: İletişim Yayınları, 1985, 1599-1603.

Sağlamtimur, Zuhal Özel. "Batılı Seyyahların Fotoğraflarında Urfa.” Harran ve Çevresi Arkeoloji. Ed. Mehmet Önal, Süheyla İrem Mutlu ve Semih Mutlu. Şanlıurfa: Elif Matbaası, 2019, 577-585.

Sachau, Eduard. Reise in Syrien Und Mesopotamien. Leipzig: F. A. Brockhaus, 1883.

Sarıtaş, İbrahim. “Alman İmparatorluğu'nun Türk Dünyasına Yönelik Propaganda Faaliyetleri: Arkeolog Max Freiherr von Oppenheim ve Doğu Haber Ajans1.” Bilig - Türk Dünyası Sosyal Bilimler Dergisi 91 (2019): 113-135.

Sarre, Friedrich ve Ernst Herzfeld. Archaeologische Reise im Euphrat und Tigris-Gebiet, Band II. Berlin: Dietrich Reimer/Ernest Vohsen A.G, 1920.

Severance, Gordon ve Diana Severance. Against the Gates of Hell: The Life \& Times of Henry Perry, A Christian Missionary in a Moslem World. USA: University Press of America, 2012.

Shaw, Wendy M. K. Osmanlı Müzeciliği-Müzeler, Arkeoloji ve Tarihin Görselleştirilmesi. Çev. Esin Soğancılar, İstanbul: İletişim Yayınları, 2020.

Tiryaki, Gökhan. "Yeni Hitit Sanatı Üzerine İkonografik Araştırmalar 1: Üzüm Salkımı ve/veya Başak Filizi Taşıyanlar." CEDRUS The Journal of MCRI 1 (2013): 33-53.

Uğurlu, A. Hilal ve Suzan Yalman. Kutsal Mekânlar ve Kentsel Ağlar. İstanbul: Anamed, 2019.

Uğurlu, A. Hilal. "Müceddid” Osmanlı Sultanı III. Selim'in Siyasi Söyleminde "Kutsalların” Rolü (h. 1789-1807).” Kutsal Mekânlar ve Kentsel Ağlar. İstanbul: Anamed Yayınları, 2019, 105-117.

Young, James O. "The Values of the Past." Appropriating the Past: Philosophical Perspectives on the Practice of Archaeology. Ed. Geoffrey Scarre and Robin Coningham. Cambridge: Cambridge University Press, 2012, 25-41.

Yücel, Erdem. "Müze.” Türkiye Diyanet Vakfi İslam Ansiklopedisi. C. 32. Ankara: Türkiye Diyanet Vakfi Yayınları, 2006, 240-243.

\section{Başkanlık Osmanlı Arşivi (BOA)}

Başkanlık Osmanlı Arşivi (BOA). A.\} Sedaret - Mektubî Kalemi Evrakı (MKT) 110/64, 7 Rebiülevvel 1848 (12 Şubat 1848).

Başkanlık Osmanlı Arşivi (BOA). A.\} Sedaret - Mühimme Kalemi Evrakı (MKT.MHM) 52/10, 30 Rebiülevvel 1269 (11 Ocak 1853).

Başkanlık Osmanlı Arşivi (BOA). A.\} Sedaret - Meclis-i Vâlâ Evrakı (MKT.MVL) 26/28, 25 Cemaziyelevvel 1266 (8 Nisan 1850)

Başkanlık Osmanlı Arşivi (BOA). A.\} Sedaret - Nezaret ve Devair Evrakı (MKT.NZD) 74/32, 26 Cemaziyelevvel 1269 (7 Mart 1853).

Başkanlık Osmanlı Arşivi (BOA). A.\} Sedaret - Umumî Vilâyat Evrakı (MKT.UM) 490/17, 1 Safer 1278 (8 Ağustos 1861).

Başkanlık Osmanlı Arşivi (BOA). Bâb-1 Ali Evrak Odası (BEO) 1815/136094, 15 Zilhicce 1319 (25 Mart 1902). 
Başkanlık Osmanlı Arşivi (BOA). Dahiliye - İdare (DH.ID) 129-1, 8 Cemaziyelevvel 1330 (25 Nisan 1912).

Başkanlık Osmanlı Arşivi (BOA). Dahiliye - İdare (DH.ID) 28/18, 1 Ramazan 1331 (4 Ağustos 1913).

Başkanlık Osmanlı Arşivi (BOA). Dahiliye - Mektubî Kalemi (DH.MKT) 2801/71, 4 Rebiülahir (4 May1s 1909).

Başkanlık Osmanlı Arşivi (BOA). Dahiliye - Mektubî Kalemi (DH.MKT) 1622/25, 8 Ramazan 1306 (8 May1s 1889).

Başkanlık Osmanlı Arşivi (BOA). Dahiliye - Mektubî Kalemi (DH.MKT) 1623/132, 19 Ramazan 1306 (19 Mayıs 1889).

Başkanlık Osmanlı Arşivi (BOA). Dahiliye - Mektubî Kalemi (DH.MKT) 1205/19, 3 Ramazan 1325 (10 Ekim 1907).

Başkanlık Osmanlı Arşivi (BOA). İrade - Hariciye (İ.HR) 409/6, 24 Şaban 1325 (2 Ekim 1907).

Başkanlık Osmanlı Arşivi (BOA). Maarif Nezareti - Mektubî Kalemi (MF.MKT) 1153/53-1-2, 17 Mayıs 1326 (30 Temmuz 1910).

Başkanlık Osmanlı Arşivi (BOA). Maarif Nezareti - Mektubî Kalemi (MF.MKT) 132/43, 27 Rebiülevvel 1309 (31 Ekim 1891).

Başkanlık Osmanlı Arşivi (BOA). Maarif Nezareti - Mektubî Kalemi (MF.MKT) 137/46, 20 Şaban 1309 (20 Mart 1892).

Başkanlık Osmanlı Arşivi (BOA). Maarif Nezareti - Mektubî Kalemi (MF.MKT) 149/58, 17 Safer 1310 (10 Eylül 1892).

Başkanlık Osmanlı Arşivi (BOA). Maarif Nezareti - Mektubî Kalemi (MF.MKT) 144/14, 18 Zilkade 1309 (14 Haziran 1892).

Başkanlık Osmanlı Arşivi (BOA). Maarif Nezareti - Mektubî Kalemi (MF.MKT) 148/110, 7 Safer 1310 (31 Ağustos 1892).

Başkanlık Osmanlı Arşivi (BOA). Maarif Nezareti - Mektubî Kalemi (MF.MKT) 693/9, 2 Muharrem 1321 (31 Mart 1903).

Başkanlık Osmanlı Arşivi (BOA). Maarif Nezareti - Mektubî Kalemi (MF.MKT) 272/38, 13 Muharrem 1313 (6 Temmuz 1895).

Başkanlık Osmanlı Arşivi (BOA). Maarif Nezareti - Mektubî Kalemi (MF.MKT) 517/59, 29 Rebiülevvel 1318 (27 Temmuz 1900).

Başkanlık Osmanlı Arşivi (BOA). Meclis-i Vâlâ (MVL) 23/14-3, 20 Cemaziyelevvel 1264 (29 Nisan 1848).

Başkanlık Osmanlı Arşivi (BOA). Maliye Nezareti Emlaki Emiriyye Müdüriyeti (ML.EEM) 847/24, 26 Mart 1327 (8 Haziran 1911).

Başkanlık Osmanlı Arşivi (BOA), Şura-yı Devlet (ŞD) 2416/20, 18 Safer 1296 (11 Şubat 1879).

Başkanlık Osmanlı Arşivi (BOA), Şura-yı Devlet (ŞD) 2447/31, 4 Rebiülevvel 1299 (24 Ocak 1882).

Başkanlık Osmanlı Arşivi (BOA), Şer‘iyye Sicil Defterleri (MŞH.ŞSC.d) 8829/117-1384, 8 Rebiülevvel 1291 (25 Nisan 1874). 